\title{
The First Amendment Right of Access to Docket Sheets
}

\author{
Meliah Thomas $\dagger$
}

\section{INTRODUCTION}

While appealing his criminal convictions to the Eleventh Circuit, Colombian drug trafficker Fabio Ochoa-Vasquez alleged instances of governmental corruption that would impress even the most imaginative of conspiracy theorists. Ochoa claimed that he had been indicted because he refused to pay a Drug Enforcement Agency (DEA) informant a $\$ 30$ million bribe; that the extortion was part of a U.S.-supported program to induce drug traffickers to surrender by selling them lenient sentences; and that program participants could surrender to U.S. authorities through phony drug busts. ${ }^{1}$ Although the Eleventh Circuit ultimately declined to adopt Ochoa's version of the facts, the court agreed with him on one point: the United States District Court for the Southern District of Florida unconstitutionally sealed docket sheets in his case as well as the cases of his codefendants. Ochoa had planned to call some of his codefendants as witnesses at his trial, but could not locate the men or their court records because their cases had disappeared from the federal court's public docket. $^{2}$ A transcript from a closed proceeding involving codefendant Orlando Sanchez-Cristancho revealed that prosecutors and defense attorneys had asked a magistrate judge to remove his case from the public docket. ${ }^{3}$ The magistrate judge responded, "[I]f you want to - me to defer, I guess I could verbally order that - that the clerk retain custody of these documents... and that they be held in the vault and not docketed."

Copyright (C 2006 California Law Review, Inc. California Law Review, Inc. (CLR) is a California nonprofit corporation. CLR and the authors are solely responsible for the content of their publications.

$\dagger \quad$ J.D., School of Law, University of Califomia, Berkeley (Boalt Hall), 2006. Professor Stephen Sugarman provided invaluable comments on earlier drafts of this piece. This Comment benefitcd substantially from the meticulous editing of the members of the California Law Review, particularly Aimée Buckland, Rebecca Hart, Ben Johnson, and Nirit Sandman. All mistakes and omissions are my own.

1. United States v. Ochoa-Vasquez, 428 F.3d 10I5, 1022-23 (1 Ith Cir. 2005).

2. Kirsten B. Mitchell \& Susan Burgess, Disappearing Dockets: When Public Dockets Have Holes, the Public's Right to Open Judicial Proceedings is Jeopardized, 30 News Media \& L. 4, 6 (2006).

3. Ochoa-Vasquez, 428 F.3d at 1028 n.13.

4. Id. 
Another of Ochoa's codefendants, Nicolas Bergonzoli, was similarly convicted, sentenced, and imprisoned in total secrecy, as his docket sheet was also sealed from public inspection. ${ }^{5}$ Emphasizing that the First Amendment right to attend criminal proceedings extends to the right of access to the proceedings' docket sheets, the Eleventh Circuit held that the district court's use of sealed dockets was unconstitutional. ${ }^{6}$

Ochoa's case is not unique. In recent years, several state and federal courts have withheld cases from public dockets and restricted individuals from inspecting docket sheets. ${ }^{7}$ A docket is a list of every case before a court. A docket sheet is the record in which a court clerk notes a case's number, the names of the parties involved, and all the proceedings and filings in a case. ${ }^{8}$ By examining a docket sheet, individuals can determine whether a case is pending or has been resolved, identify the documents that have been submitted to the court, and find out when hearings and arguments will be held. Most jurisdictions boast a lengthy history of public access to docket sheets.

In discussing sealed dockets, this Comment refers to instances where a judge has removed a case's number from the public docket and has rendered the docket sheet unavailable for public inspection. Sealing a docket prevents the public from ascertaining a case's number, the names of the parties involved, and whether any filings or proceedings have taken place. In essence, sealing a docket sheet entirely prevents the public from knowing of a case's existence. Cases with sealed dockets have surfaced only by pure chance. In one instance, a court's clerical error revealed the existence of a "super-sealed" case. ${ }^{9}$ In another, reporters uncovered an entire system of secret docketing after talking to court personnel and attorneys. $^{10}$

5. Mitchell \& Burgess, supra note 2, at 4.

6. Ochoa-Vasquez, 428 F.3d at 1029-30.

7. See, e.g., Hartford Courant Co. v. Pellcgrino, 380 F.3d 83, 93 (2d Cir. 2004); United States v. Valenti, 987 F.2d 708, 715 (11th Cir. 1993); In re State-Record Co., 917 F.2d 124 (4th Cir. 1990) (per curium); Globe Newspaper Co. v. Fenton, 819 F. Supp. 89, 90 (D. Mass. 1993); State ex rel. Cincinnati Post v. Court of Appeals, 604 N.E.2d 153 (Ohio 1992); see also Gwen Filosa, Case Against Ex-Judge Sealed; Gag Order Also Issued in Unusual Move, T1MES-PTCAYUNE, Apr. 21, 2004, at 1 (reporting that docket cntries were sealed in perjury prosecution involving former judge); Mitchell \& Burgess, supra note 2 (reporting that $18 \%$ of nearly 3000 criminal cases were not docketed in Washington, D.C.'s federal district court).

8. Although there is a distinction betwcen a docket, which is a list of every case before a court, and a docket sheet, which contains a list of every proceeding in an individual case, for purposes of simplicity the Comment uses the terms interchangeably.

9. See Petition for Writ of Certiorari at 7, M.K.B. v. Warden, 540 U.S. 1213 (No. 03-6747) (2004) [hereinafter Petition for Writ of Certiorari]; Dan Christensen, Secrecy Within, DaILY Bus. Rev., Mar. 12, 2003, at A1 [hereinafter Secrecy Within].

10. See Thomas B. Scheffey, State Divorce Courts Quick to Cloak Cases, Conn. L. TRIB., Dec. 2, 2002, at 1; Lynne Tuohy, No Docket, No Names; Cases Move in Secrecy, HarTford Courant, Jan. 5,2003 , at $\mathrm{A} 1$. 
Without public docket sheets "there is no way for the public to even know that a case has been brought or resolved."11 As a result, sealed dockets greatly impair, if not extinguish, the public's ability to attend court proceedings and inspect documents. Given the compelling public interest in discussing and publishing information related to the judicial process, this Comment argues that public access to docket sheets must be afforded First Amendment protection. ${ }^{12}$ It defines the right of access to docket sheets as the right of any member of the public to examine a docket sheet and the entries contained therein. ${ }^{13}$ First Amendment protection of this right of access inheres in the Amendment's guaranteed freedoms of speech and press, for the "explicit, guaranteed rights to speak and publish concerning what takes place at a trial would lose much meaning if access to observe the trial could ... be foreclosed arbitrarily."14 In addition, access to docket sheets serves as a gateway and prerequisite to a variety of rights that enhance self-governance and improve the functioning of the judicial system, such as the public's First Amendment right to attend criminal trials. Accordingly, access to docket sheets warrants First Amendment protection. Denial of such access significantly stifles the public's ability to speak and publish on matters involving the court system.

Part I of this Comment examines the history and purpose of docket sheets and discusses recent cases, both civil and criminal, in which courts have sealed dockets. Part II details the history of both the common law and First Amendment rights of access to governmental institutions, with a particular emphasis on the courts. It then examines how this jurisprudence can be construed to assert a First Amendment right of access to docket sheets. Part III outlines the contours of such a right, including the details that a docket sheet must contain in order to meet First Amendment standards. It also applies Supreme Court precedent to determine the narrow circumstances in which courts can restrict public access to docket sheets, and provides examples of potential compelling interests that outweigh the

11. Ann W. O'Neill, Watchdog Challenges Secrecy in U.S. Court, Sun-Sentinel, Jan. 8, 2004, at $1 \mathrm{~A}$ (quoting renowned First Amendment attorney Floyd Abrams).

12. See U.S. ConST. amend. 1 ("Congress shall make no law ... abridging the freedom of speech, or of the press.").

13. The Comment does not address the extent to which members of the public should be allowed to examine the various court documents recorded as entries on docket sheets, such as discovery materials, pleadings, and motions.

14. See Richmond Newspapers, Inc. v. Virginia, 448 U.S. 555, 576-77 (1980) (plurality opinion) (Burger, C.J.) ("In guaranteeing freedoms such as those of speech and press, the First Amendment can be read as protecting the right of everyone to attend trials so as to give meaning to those explicit guarantees."); see also Thomas 1. Emerson, Legal Foundations of the Right to Know, 1976 WASH. U. L.Q. 1, 2 (1976) (describing a "right to know" government information as implicit in the First Amendment's guarantee of freedom of expression); Sigman L. Splichal, The Right to Know, in AccEss Denied: Freedom of Information in the Information Age 16 (Charles N. Davis \& Sigman L. Splichal eds., 2000) (noting that the First Amendment right of access to criminal trials is implicit in the Amendment's guarantees of freedom of speech and press). 
public's interest in access. Such examples include protecting the identities of juveniles involved in criminal prosecutions, parties involved in adoption proceedings, and defendants cooperating with the government in multidefendant prosecutions.

Finally, because the First Amendment right of access to docket sheets has not been widely litigated, this Comment suggests that until the right is broadly accepted and honored, advocates should take affirmative steps to vindicate such a right. Part IV explores three approaches advocates can take to accomplish this goal: (1) initiate litigation; (2) lobby legislators to adopt laws limiting the sealing of docket sheets; and (3) pressure courts to adopt rules restricting the practice. It reveals that each tactic has its own strengths and weaknesses, and that a combination of the three approaches discussed may yield the ideal set of protections.

I

\section{The Purpose and Sealing of Dockets}

Part I of this Comment examines the type of information that may be gleaned from dockets, the constituencies that often seek access to this information, and the ways in which access to docket information may be restricted. The Comment then moves to a discussion of recent cases in which docket sealing was sought, examining three major categories of cases: civil, criminal, and habeas corpus. As will be illustrated, dockets have been sealed in both federal and state courts, as well as at the trial and appellate levels, suggesting that docket sealing is not limited to a few anomalous jurisdictions. This background is intended not only to raise awareness regarding the practice of docket sealing, but aIso to show that the practice may infringe upon the rights of parties to litigation as well as conceal information that is relevant to the public interest.

\section{A. The History, Treatment, and Importance of Dockets}

Although the Introduction provided a brief description of dockets and docket sheets, a more detailed discussion follows below, which will help lay the foundation for the rest of the discussion throughout this Comment. A docket is "a list of every case before the court"15 and provides "a kind of index to judicial proceedings." 16 Individual cases in a court system usually are numbered chronologically based upon the date on which they were filed. ${ }^{17}$ As noted earlier, a docket sheet is a record that contains each case's

15. Federal Judicial Center, Clerk of Court and Clcrk's Office Staff, http:/www.fjc.gov/federal courts.nsf/autoframe?OpenForm\&nav=menu5\&page $=/$ federal/courts.nsf/page $/ 3 C E 95 B 37966698$ B9852 5682A006FB899?opendocument (last visited Apr. 1, 2006).

16. Hartford Courant Co. v. Pellegrino, 380 F.3d 83, 93 (2d Cir. 2004).

17. See FED. R. Civ. P. 79. 
number, "the names of the parties, and a minute of every proceeding." 18 In federal courts, for example, "[a]ll papers filed with the clerk, all process issued and returns made thereon, all appearances, orders, verdicts, and judgments" are entered chronologically on docket sheets. ${ }^{19}$ These entries, although brief, "show the nature of each paper filed or writ issued and the substance of each order or judgment of the court."20 Docket sheets thus do not divuIge the substance of the documents filed in a particular case; rather, "[t]hey merely note their presence."21

By examining a docket sheet, individuals can determine whether a final judgment has been issued in a case, whether it has been dismissed, or whether it is still pending; identify the documents that have been filed, including reply briefs, motions to intervene, motions to remove, motions to remand, or motions to change venue; and find out when hearings and arguments will be held. ${ }^{22}$ The case numbers included on docket sheets in most jurisdictions indicate whether a particular matter is criminal or civil, a distinction that becomes crucial if members of the public or press seek to monitor criminal proceedings. In most federal and state courts, for example, the number for a criminal case contains the Ietters $C R$, while civil case numbers contain the designation $C V .^{23}$ In many federal district courts, the case number also includes the presiding judge's initials or a code indicating the judge assigned to the case. ${ }^{24}$ Finally, docket sheets alert members of the public to the filing of motions to seal court documents and proceedings, thereby giving the public an opportunity to oppose such motions. ${ }^{25}$ In sum: "It is not misleading to think of courthouse papers as comprising a vast library of volumes for which docket sheets are the tables of contents. Without [docket sheets], a reader is left without a meaningful

18. JOHN BOUVIER, LAW DictionaRY (6th ed. 1856), http://www.constitution.org/bouv/ bouvier_d.htm; see also BLACK's LAw DictionARY (7th ed. 1999) (defining a docket as "[a] formal record in which a judge or court clerk briefly notes all the proceedings and filings in a court case").

19. FED. R. Civ. P. 79. Clerks of the courts of appeals have similar docketing responsibilities. FED. R. APP. P. 12, 45.

20. FED. R. CIV. P. 79.

21. Reply Brief of Plaintiffs-Appellants at 3, Hartford Courant Co. v. Pellegrino, 380 F.3d 83 (2d Cir. 2004) (No. 03-9141).

22. See Hartford Courant Co. v. Pellegrino, 380 F.3d 83, 95-96 (2d Cir. 2004) ("By inspecting materials like docket sheets, the public can discern the prevalence of certain types of cases, the nature of the parties to particular kinds of actions, information about the settlement rates in different areas of law, and the types of materials that are likely to be sealed."); see also Globe Newspaper Co. v. Fenton, 819 F. Supp. 89, 90 (D. Mass. 1993) ("From the docket sheets it is possible to identify what papers in the case file may relate to particular action that took place during the proceeding.") (quoting Globe Newspaper Co. v. Pokaski, 868 F.2d 497, 499 n.4 (1 st Cir. 1989)).

23. See, e.g., D. Ariz. Local R. 3.2 (2005); D. Conn. Local R. 79 (2005); Ark. Sup. Ct. Adm. Order No. 2 (2005); TEX. R. ApP. P. 12 (2006).

24. See, e.g., D. Ariz. Local R. 3.2 (2005); D. Conn. Local R. 79 (2005); M.D. Fla. Local R. 1.03 (2005); D. KaN. Local R. 77.3 (2005); D. Nev. Local R. 10-2 (2005); D.N.H. Local R. 5.1 (2005).

25. See Pellegrino, 380 F.3d at 93 ("[T]he docketing of a hearing on sealing provides effective notice to the public that it may occur."). 
mechanism by which to find the documents necessary to learn what actually transpired in the courts."26

Historically, dockets and docket sheets have been open for public inspection. According to Tomlins' Law Dictionary, judgments from the Common Bench in England were "docketted, and entered on the docket of that term; so that upon any occasion you may soon find out a judgment, by searching these dockets, if you know the attorney's name."27 State statutes have long mandated that clerks maintain records of judicial proceedings in docket books, ${ }^{28}$ "which were presumed open either by common law or in accordance with particular legislation." 29

It is difficult to quantify which groups seek access to docket sheets most often or have the greatest need for the information that docket sheets provide. Even so, three constituencies stand out in that they often seek access: journalists, attorneys, and members of advocacy organizations, such as judicial reform groups or groups that author amicus briefs. First, many of the cases challenging docket sealing have been brought by media plaintiffs, indicating that members of the press may comprise a significant percentage of the individuals who seek access to docket sheets. ${ }^{30}$ Press members often consult dockets to determine whether there have been any developments in high-profile cases, especially if the proceedings or filings in such cases are not open to the press. ${ }^{31}$ Second, docket sheets enable attorneys to monitor the status of pending cases that, when resolved, may have precedential value for legal matters affecting their clients. Third, members of advocacy organizations seek access to docket sheets so that they can attend oral arguments, monitor the outcome of particular cases,

26. Fenton, 819 F. Supp. at 94.

27. T.E. Tomlins, The LAW-Dictionary (1811) (emphasis in original).

28. See, e.g., 705 ILl. Comp. Stat. ANn. 105/16 (originally enacted 1887); Mich. Comp. Laws $\S 774.3$ (originally enacted 1879); MONT. CODE ANN. $\$ 3-5-509$ (originally enacted 1867); NEV. REV. STAT. 17.170 (originally enacted 1911); N.J. STAT. ANN. § 2A:18-37 (originally enacted 1898); N.Y. JuD. LAW $\$ 255$-b (originally enacted 1920).

29. Pellegrino, 380 F.3d at 94; see also Fenton, 819 F. Supp. at $92-93$ (noting that in Massachusetts, "[ $t$ ] he legislative mandate that the clerks maintain alphabetical indices [of the names of all parties to a judicial action] has continued uninterrupted for the past two centuries").

30. See, e.g., Pellegrino, 380 F.3d at 93; Fenton, 819 F. Supp. at 90; State ex rel. Cincinnati Post v. Court of Appeals, 604 N.E.2d 153 (Ohio 1992).

31. See, e.g., Traey Breton, Operation Plunder Dome - Sealed Documents Accumulating Quickly in Federal Court File, Providence J.-Bull., May 15, 2001, at 1A (reporting that in federal corruption case against city official, docket showed that sealed documents had been filed with the court); David Hanners, Teen Faces Two Federal Charges, Duluth News Trib., June 2, 2005, at 1 (reporting that in juvenile criminal trial where initial hearings were closed to the public, docket sheet entries revealed that juvenile's attorney had tried to get his client released from federal custody); Neil A. Lewis, Testing of a President: The Media; Court Rebuffs Press's Bid for Access to Hearings, N.Y. Times, May 6, 1998, at 21 (reporting that in grand jury investigation of President Clinton, list of sealed proceedings were placed on public docket so that press might have an opportunity to object); Eric Lichtblau, Sept. 11 Suspect May Be Set To Agree to Plead Guilty, N.Y. TIMES, Apr. 20, 2005, at 22 (reporting that in case in which judicial order barred parties from discussing details outside the eourtroom, court docket reflected that Sept. Il suspect Zacarias Moussaoui had filed several sealed motions). 
determine the timing for the filing of amicus briefs, ${ }^{32}$ or even file motions to intervene. Domestic violence prevention organizations, in particular, actively scrutinize the family courts. They use docket sheets to determine when hcarings have been scheduled in child custody and restraining order cases, as well as to monitor the outcomes in such cases. ${ }^{33}$

Parties to an action may attempt to restrict public access to docket sheets in several ways. The most extreme measure involves asking the court to seal the entire case file, including the case's docket sheet. By following this route, parties can prevent the public from even knowing of a case's existence.

In other instances, the parties to an action may agree that the docket sheet will remain open to the public, but they will ask the court not to docket specific proceedings or filings. As a result, the public would maintain the ability to ascertain a case's docket number and the names of the parties involved, and could thus at least know that the case exists. However, the public would not have access to the complete history of the proceedings in the case. A court might not record some of the proceedings on the public docket sheet at all, or it might record such proceedings and files as a "SEALED HEARING" or "SEALED FILING." In extreme cases, parties may ask that most or even all of the entries on the docket sheet be listed as sealed.

It is important to distinguish between the sealing of a docket sheet and the sealing of the files in a case. If a docket sheet has been sealed in a case, the public cannot view the court's record of the proceedings in that case. In other words, when a docket sheet is sealed, the table of contents of a particular case file is not available to the public. Sealing the docket sheet essentially results in the sealing of an entire case file, because individuals will have virtually no way of knowing that any documents have been filed in a case, or that a casc even exists. ${ }^{34}$ The only way to determine whether

32. In the California Supreme Court, for example, amicus curiae briefs must be filed no later than thirty days after the parties to the litigation have filed their briefs on the merits and their reply briefs. CAL. R. CT. 29.1 (2006), http://www.courtinfo.ca.gov/rules/titleone/title1-1-59.htm\#TopOfPage. By viewing a docket sheet, an organization that wishes to write an amicus curiae brief can determine when the parties to the litigation filed their briefs, and, in turn, when amicus curiae briefs must be filed with the court.

33. See generally Eric Collins, Judges Pushed to Grant Custody, News \& Rec. (Greensboro, N.C.), Jan. 22, 2006, at B1 (reporting findings of advocacy group that monitored twelve judges over five years and concluded that many judges had refused to grant temporary child custody to domestic violence victims); Jessie Halladay, Group Proposes Domestic Violence Court, Courier-J. (Louisville, Ky.), Mar. 6, 2006, at IB (reporting findings of advocacy group that monitored family law courts since 1995 and recommended that state district court create separate domestic violence court). It should be noted, however, that some jurisdictions permit parties in domestic-violence-related proceedings to seal court documents or automatically seal such documents. See, e.g., N.J. STAT. ANN. § 2c:25-33 (West 2005); Мich. Ст. R. 8.119 (2006).

34. It is possible that if an individual knew a case's number before its docket sheet was sealed, and the case's files themselves remained open, the individual theoretically could look up the case at the 
such cases exist "is to scroll through public dockets searching for missing case numbers." 35

On the other hand, sealing the files of a case means that the public cannot view the actual content of any documents that have been submitted to the court, such as pleadings or motions. In most instances, when parties move to seal particular documents or proceedings in a case, the fact that such documents were filed or that the proceedings took place will still be recorded on the docket sheet.

Parties may seek to seal dockets for several reasons. Although little empirical research has been done to quantify the types of cases in which dockets are sealed most often, news stories and case law indicate that criminal dockets are sealed more often than civil dockets. ${ }^{36}$ A recent study of the United States District Court for the District of Columbia, prepared by the Reporters' Committee for Freedom of the Press, found that most of that district's cases with sealed dockets were criminal cases. ${ }^{37}$ According to court officials and lawyers with access to the cases who were interviewed for the study, the cases missing from the district court's criminal docket were typically gang-related prosecutions involving multi-defendant drug and murder conspiracy trials. ${ }^{38}$ Few, if any of the cases, were terrorism related. ${ }^{39}$ Many of the civil off-the-docket cases were believed to be whistleblower suits filed under the federal False Claims Act. ${ }^{40}$

News stories indicate that dockets also have been sealed in family law disputes (such as divorce, paternity, and child support proceedings)

courthouse or online and view the case files. See Fenton, 819 F. Supp. at 96 (noting that court's alphabetical index of cases was sealed from public view, but that case files were still open for inspection).

35. See Mitchell \& Burgess, supra note 2, at 4.

36. See, e.g., United States v. Ochoa-Vasquez, 428 F.3d 1015 (11th Cir. 2005) (holding unconstitutional a system of dual docketing in a district court's criminal cases); United States v. Valenti, 987 F.2d 708 (11th Cir. 1993) (same); In re State-Record Co., 917 F.2d 124 (4th Cir. 1990) (per curium) (directing district court to reconsider sealing of docket sheets in certain criminal matters because order requiring such sealing was likely overbroad); see also Filosa, supra note 7 , at 1 (reporting that docket entries were sealed in pcrjury prosecution involving former judge); Mitchell \& Burgess, supra note 2, at 4 (reporting that 18 percent of nearly 3,000 criminal cases wcre not docketed in Washington, D.C.'s federal district court); Gerard O'Neill \& Dick Lehr, State Stumbles in Pursuit of Political Corruption, Boston Globe, Dec. 10, 1989, at 1 (describing inability of reporters to obtain docket sheets for cases involving criminal prosecution of political corruption).

37. Mitchell \& Burgess, supra note 2 , at 4 .

38. Id.

39. Id.

40. Id. Under the False Claims Act, private individuals may sue on the United States' behalf, charging fraud by contractors and other organizations recciving or using government funds. 31 U.S.C. $\S 3730$ (2000). By statute, the suits are filed under seal for sixty days, allowing the government to investigate the alleged wrongdoing and determine whether to intervene in the case. Id. Mitchell \& Burgcss, supra note 2 , at $4 ; 31$ U.S.C. $\$ 3730$. Once the investigation is complete, the suits may or may not appear on the docket. Mitchell \& Burgess, supra note 2, at 4. 
involving prominent businesspeople or public officials ${ }^{41}$ and in disciplinary or disability proceedings involving attorneys and judges. ${ }^{42}$ By statute or court rule, dockets are sealed in some jurisdictions in certain types of cases involving the prosecution of juveniles. ${ }^{43}$ Similarly, several jurisdictions have statutes or court rules restricting public access to adoption dockets. ${ }^{44}$

It is difficult to determine whether, on the whole, docket sealing is usually sought by both parties to a proceeding or by only one party over the objections of the other. Cases challenging docket sealing have involved instances where all parties agreed to seal the docket, ${ }^{45}$ as well as instances where a party to the litigation unsuccessfully opposed the sealing of the docket. ${ }^{46}$ In multi-defendant prosecutions where a defendant cooperates with the government and may be subject to retaliation, both the prosecution and defense might seek docket sealing to protect the defendant's safety. ${ }^{47}$ If a defendant has refused to cooperate with the government in a multidefendant prosecution, and there is an ongoing criminal investigation, the government still might seek to seal the docket to prevent co-conspirators and the media from learning information regarding the defendant's case, such as whether the defendant was tried, convicted, and sentenced ${ }^{48} \mathrm{~A}$ defendant might oppose sealing because he wants the public to be able to scrutinize his case ${ }^{49}$ In Connecticut, where the courts employed a system of secret docketing to conceal family law matters, news stories indicated that the parties to litigation sometimes opposed sealing. ${ }^{50}$

41. Dave Altimari, Court's Secrets in a New Light; Documents Show How Cases Were Concealed, HARTFord Courant, May 1, 2005, at A1.

42. Nancy West, Secret Court Docket Revealed, N.H. Sunday News, Sept. 3, 2000, at 1.

43. See, e.g., CAL. Welf. \& INST. CODE $\$ 389$ (2006); Fla. STAT. $\$ 39.0132$ (2005); MD. R. 1 I121 (2006). But see IDAHo CODE ANN. $\$ 20-525$ (2005) (mandating that dockets for proceedings involving juveniles age fourteen and older be open to the public).

44. See, e.g., Del. Code ANN. tit. 13, § 1112 (2005); GA. CodE ANN. § 19-8-23 (2005); Haw. REV. STAT. 578-15 (2005).

45. See United States v. Ochoa-Vasquez, 428 F.3d 1015, 1028 (1 Ith Cir. 2005) (quoting transcript from proceeding in which both prosecution and defense attorneys requested court to seal docket).

46. See Petition for Writ of Certiorari, supra note 9, at 9 (noting habeas corpus petitioner's repeated efforts to unseal docket and proceedings in his case); Ochoa-Vasquez, 428 F.3d at 1028 (noting that Ochoa-Vasquez, a defendant in a multi-defendant drug conspiracy prosecution, sought to unseal his own case docket and files).

47. See Ochoa-Vasquez, 428 F.3d at 1028; Mitchell \& Burgess, supra note 2, at 5 (quoting an official from the Office of the Federal Public Defender for the District of Columbia as stating: "[T]here are people who would be in serious danger, who would be killed, if it was known they cooperated with the govemment.... [A]ll the stake holders in the situation understand that and so the case is sealed to protect the individual.").

48. See generally Ochoa-Vasquez, 428 F.3d at 1028.

49. See Petition for Writ of Certiorari, supra note 9, at 24-26 (noting that sealing of docket in habeas petitioner's case removed his legal plight from public debate); Mitchell \& Burgess, supra note 2 , at 8 (quoting Ochoa-Vasquez's attorney as stating that "sealing helped prevent the public and the media from doing their job").

50. See Tuohy, supra note 10, at Al. 
It is also unclear whether courts have practiced docket sealing for several decades, or whether the procedure is a recent phenomenon. The Connecticut state courts had a secret docketing system for nearly forty years, but the practice was not adjudicated as unconstitutional until 2004. ${ }^{51}$ The New Hampshire state courts had a secret docket with cases dating back to 1985 , which was dismantled in 2001 in response to public outcry. ${ }^{52}$ Most challenges to sealed dockets have been brought within the past two decades. ${ }^{53}$ The recentness of these cases is likely related to courts' increased willingness to recognize the rights of access to court proceedings and documents during the $1980 \mathrm{~s}$ and $1990 \mathrm{~s}^{54}$

As noted above, a court's authority to seal a docket in a particular proceeding may derive from statutes or court rules, such as in cases involving adoption proceedings or prosecutions of juveniles. More commonly, a court's authority to seal a docket derives from the fact that the right to inspect and copy judicial records is not absolute. ${ }^{55}$ None of the federal courts' oversight agencies have promulgated rules explicitly authorizing the sealing of dockets. ${ }^{56}$ Nevertheless, the Supreme Court has recognized that courts have supervisory power over their own records and files, and that access can be denied where court documents might become "a vehicle for improper purposes." "57

There does exist a common-law presumption of access to judicial records. This presumption, however, may be rebutted if "countervailing interests heavily outweigh the public interests in access." ${ }^{\circ 8}$ Similarly, some courts have recognized a First Amendment right of access to certain court documents, such as transcripts of criminal proceedings. Like the commonlaw presumption, this right has not been deemed absolute by the courts. It may be refuted if: (1) closure is essential to preserve higher values than the public's right of access; (2) there is a substantial probability that, in the absence of closure, those values would be harmed; and (3) there are no reasonable alternatives to closure that would adequately protect those values. ${ }^{59}$ Thus, assuming (as this Comment argues) that there is a First

51. Hartford Courant Co. v. Pellegrino, 380 F.3d 83, 86 (2d Cir. 2004).

52. Nancy West, Court Adopts Temporary Rule on Confidentiality, N.H. Sunday News, July 8 , 2001 , at $\mathrm{A} 3$.

53. See, e.g., Pellegrino, 380 F.3d at 86; United States v. Valenti, 987 F.2d 708, 715 (11th Cir. 1993); In re State-Record Co., Inc., 917 F.2d 124 (4th Cir. 1990) (per curium); Globe Newspaper Co. v. Fenton, 819 F. Supp. 89, 90 (D. Mass. 1993); State ex rel. Cincinnati Post v. Court of Appeals, 604 N.E.2d 153 (Ohio 1992).

54. The development of the First Amendment right of access to court proceedings and documents is discussed in detail in Part II.A, infra.

55. See Nixon v. Wamer Commc'ns, Inc., 435 U.S. 589, 598 (1978).

56. Mitchell \& Burgess, supra note 2, at 8.

57. Nixon, 435 U.S. at 598.

58. Rushford v. New Yorker Magazine Inc., 846 F.2d 249, 253 (4th Cir. 1988).

59. Press-Enter. Co. v. Superior Court (Press-Enter. II), 478 U.S. 1, 13-14 (1986). 
Amendment right of access to docket sheets, if a court finds that the sealing of a docket meets the above criteria, it is within the court's authority to seal a particular docket.

To better explain the impact that the sealing of docket sheets may have on the public, the rest of this Part examines cases in which docket sheets have been sealed in the past.

\section{B. The Sealing of Civil Dockets}

This Section examines cases in which the sealing of civil dockets attracted national attention and led to intense debate on issues of national security and privacy. This Comment treats habeas corpus proceedings separately from other civil proceedings because of their close connection to the criminal system, as well as the unique liberty interests sought to be enforced in these actions. Habeas proceedings test the legality of an individual's imprisonment. Thus, such proceedings implicate both the public's confidence in the criminal justice system and the basic fairness of the procedures used to impose criminal sentences in the first place. Further, access to habeas proceedings enables members of the public to independently monitor such proceedings to determine whether prisoners are being detained fairly and improves the appearance of fairness in those proceedings. Both the habeas proceedings and other types of civil cases examined in this Section illustrate that by sealing a docket, a court can conceal cases dealing with matters of public importance from outside scrutiny.

\section{Sealing Habeas Corpus Cases}

Anıong the most controversial and widely publicized instances of docket sealing was the case of Mohamed Kamel Bellahouel, one of hundreds of men of Middle Eastern descent detained after September $11 .^{60}$ As will be illustrated in the following study of Bellahouel's case, sealing docket sheets in habeas corpus cases reduces the appearance of fairness in such cases; hinders the habeas petitioner's ability to present his case; prevents advocates from monitoring the integrity of proceedings; and restricts the public from engaging in fully informed discourse on matters such as the treatınent of post-September 11 detainees.

In Bellahouel's case, a federal district court and a court of appeals sealed an entire habeas corpus proceeding and appeal, including "the case numbers, the names of the parties and their counsel, every court filing and

60. Petition for Writ of Certiorari, supra note 9, at 3. Bellahouel and his federal public defender were barred from discussing his case or being photographed because of a gag order. See id. at 23; Secrecy Within, supra note 9, at A1; Daniel de Vise, Immigrant Tests Secrecy in War on Terrorism, Miami Herald, Jan. 19, 2004, at 1 A. 
every court ruling," all without ever entering a sealing order. ${ }^{61}$ Bellahouel, an Algerian native married to a U.S. citizen, was initially detained for overstaying his student visa. ${ }^{62}$ His detention, however, was extended to permit the Federal Bureau of Investigation (FBI) to conduct an investigation of his alleged links to two of the September 11 hijackers. ${ }^{63}$

Bellahouel brought a habeas corpus petition challenging his deportation proceedings while being held at a detention center in Miami-Dade County. A federal judge for the Southern District of Florida sealed Bellahouel's habeas proceeding from the outset. ${ }^{64}$ The secrecy was so complete that the case was kept off the public docket even though the district court judge never entered an order to seal the docket or any of the individual filings in the case. ${ }^{65}$ The district court also did not provide notice of the sealing of the docket or hold a hearing on the sealing of the case. ${ }^{66}$ To top things off, a court order prohibited the parties and their counsel from speaking publicly about the proceedings. ${ }^{67}$

Bellahouel spent five months in custody, during which time he was transported to Alexandria, Virginia, to testify before the grand jury that indicted accused September 11 co-conspirator Zacarias Moussaoui. ${ }^{68} \mathrm{He}$ was released in March 2002 on an immigration bond without being criminally charged, ${ }^{69}$ and his habeas case challenging his pending deportation proceedings proceeded in the Eleventh Circuit. ${ }^{70}$

61. Petition for Writ of Certiorari, supra note 9, at 9. In an amicus curiae brief supporting the unsealing of the lower courts' files in the habeas corpus proceeding, the Reporters' Committee for Freedom of the Press described the case as "perhaps the most egregious recent example of an alarming trend toward excessive secrecy in the federal courts, particularly in cases that bear even a tangential connection to the events of Sept. 1 I, 200I." Brief for Reporter's Committee for Freedom of the Press as Amici Curiae Supporting Petitioner at 1, M.K.B. v. Warden, 540 U.S. 1213 (2004) (No. 03-6747) [hereinafter M.K.B. Amici Curiae Brief].

62. Petition for Writ of Certiorari, supra note 9, at 3.

63. Warren Richey, Supreme Court Decision May Limit Access to Terror Cases, Christian SCI. Monitor, Feb. 24, 2004, at 04.

64. M.K.B. Amici Curiae Brief, supra note 61, at 7-8. The district court originally maintained no public docket at all in Bellahouel's case, and it later listed all sixty-five docket entries as "SEALED." ld.

65. Petition for Writ of Certiorari, supra note 9, at 8. Although the Southern District of Florida's local rules permit sealing of documents upon the request of a party, no procedures exist under which a district court can remove an item from the public docket. Instead, the Local Rule implies that sealed matters should be placed on the public docket, requiring the clerk to "note on each [sealed file's] envelope the date of filing and docket entry number." S.D. FLA. LOCAL R. 54(B)(I).

66. Petition for Writ of Certiorari, supra note 9, at 24 .

67. Id. at 23 .

68. Given the secrecy surrounding Bellahouel's case, it is difficult to assess the reasons for the government's actions against him. According to newspaper accounts, Bellahouel worked as a waiter in a restaurant that the FBI said was patronized by at least two of the September 11 hijackers. Linda Greenhouse, News Groups Seek to Open Secret Case, N.Y. Times, Jan. 5, 2004, at A12.

69. Petition for Writ of Certiorari, supra note 9 , at 7.

70. Greenhouse, supra note 68 , at A12. 
Bellahouel's case became public when a clerk inadvertently listed it on the Eleventh Circuit's public oral argument calendar and on PACER, ${ }^{71}$ prompting a newspaper story on the elaborate secrecy surrounding the proceedings. ${ }^{72}$ Although the clerical error revealed only the caption of the case and its number, this information was quickly removcd by the appellate court's staff. ${ }^{73}$ The oral argument on Bellahouel's appeal later took place in a sealed courtroom. ${ }^{74}$ Like the district court, the Eleventh Circuit issued rulings in the habeas case that remain sealed. ${ }^{75}$

Bellahouel moved to unseal the record in his case in both the district court and the court of appeals. ${ }^{76}$ The district court perfunctorily denied Bellahouel's motion in a single-sentence order stating, "Petitioner's motion to unseal certain pleadings and motion to unseal the entire record in the case are DENIED." "77 The court of appeals affirmed the district court's refusal to unseal "without identifying reasons articulated by the district court, or articulating any reasons of its own." 78 Ironically, the court of appeals' ruling that denied Bellahouel's motion to unseal was not posted on the public docket. ${ }^{79}$

Bellahouel sought Supreme Court review, challenging the sealing of "the entire docket of proceedings in the district court and the court of appeals, without articulating any findings to support sealing." ${ }^{80}$ His petition for certiorari, styled M.K.B. v. Warden, was released to the public, although it was heavily redacted. ${ }^{81}$ The government's opposition brief to

71. Public Access to Court Electronic Records (PACER) is "an electronic public acccss service that allows users to obtain case and docket information from Fedcral Appcllate, District and Bankruptcy courts." Public Access to Court Electronic Records, Overview, http://pacer.psc.uscourts.gov/pacerdesc.html (last visited Nov. 5, 2005).

72. Petition for Writ of Certiorari, supra note 9, at 7; Secrecy Within, supra note 9, at A1.

73. Pctition for Writ of Certiorari, supra note 9, at 7. When asked about the removal of Bellahouel's case from PACER, the Eleventh Circuit's chief deputy clerk said, "[w]e made a mistake. It shouldn't have been put out in the first place." Secrecy Within, supra note 9, at A15.

74. Petition for Writ of Certiorari, supra note 9, at 7. A reporter for a legal-affairs newspaper attempted to attend the hearing, but he was told by courtroom personnel that the proceeding was closed to the press and the public. De Vise, supra note 60 , at $1 \mathrm{~A}$.

75. Petition for Writ of Certiorari, supra note 9, at I0. According to the petition for certiorari, Although the secret court of appeals' decision ordered the district court to docket the case publicly [citation redacted], it affirmed the district court's refusal to unseal any of the filings in the case, and every entry in the case remains sealed. The court of appeals itself refuses to disclose that it has decided the appeal. Indeed, the final order of the court of appeals is sealed, Id. not publicly docketed.

76. Id. at 17 .

77. Id. at 19 .

78. Id. at 20 .

79. Id.

80. Petition for Writ of Certiorari, supra note 9, at iv.

81. Indeed, sevcral pages of the publicly released petition for certiorari are entirely redacted. Id. at 4-7. The public version of the petition does not even contain Bellahouel's name or indicate which circuit the petition for certiorari is from. See id. at I ("M[ ] K [ ] B. respectfully petitions the Supreme Court of the United States for a writ of certiorari to review the sealed and unpublished judgment of the 
Bellahouel's petition for certiorari was filed under seal. ${ }^{82}$ The Supreme Court denied certiorari. ${ }^{83}$ As a result, Bellahouel's case was essentially "heard, appealed, and decided in complete secrecy." 84

ln response to M.K.B., a liberal advocacy group filed a Freedom of Information Act Request with the Department of Justice (DOJ) seeking information on how often federal court proceedings involving postSeptember 11 immigrant detainees have been sealed. ${ }^{85}$ During a subsequent hearing on the request, a DOJ lawyer told a federal judge that the department would have difficulty responding to the request because sealing cases in their entirety is "not as rare as it seems."

The sealing of dockets in habeas cases, such as Bellahouel's, is particularly troubling because of the deprivation of liberty involved in habeas matters, as well as the close connection between these cases and the criminal justice system. Arguably, public access to habeas proceedings and court documents should be treated in roughly the same manner as criminal proceedings because of the significant amount of process that is typically afforded to litigants in these areas. Despite this, the justification for Mohamed Bellahouel's detainment, the nature of the conditions under which he was held, and his arguments in support of habeas relief remain a mystery because all the court documents in his case, including the dockets, are sealed.

Because Bellahouel was petitioning for habeas relief, civil libertarians and members of the press found the sealing of dockets in his case to be particularly egregious, and the actions of the federal courts involved drew national attention. As the next Section will illustrate, the sealing of dockets also raises concerns about judicial propriety in more typical forms of civil litigation, where only private parties are involved and no deprivations of liberty are at issue.

United States Court of Appeals for the [ ] Circuit ...." (redactions in original)). Further, all citations to the lower courts' rulings are redacted. See id. at 17-20.

82. See M.K.B. v. Warden, 540 U.S. 1213, 1213 (2004); Charles Lane, White House Told to Justify Secrecy; High Court Issues Order in Terror Case, WASH. POST, Nov. 5, 2003, at A06. Initially, U.S. Solicitor Theodore B. Olson declined to respond to Bellahouel's petition for certiorari, but the Court directed the government to respond. Lane, supra, at A06. Olson's eventual response was filed under seal. See Motion for Leave to File Brief in Opposition with Appendix Under Seal, M.K.B. v. Warden, 540 U.S. 1213 (2004) (No. 03-6747); Charles Lane, Court Denies Review of Post-9/11 Secrecy, WASH. Post, Feb. 24, 2004, at A06.

83. M.K.B., 540 U.S. at 1213.

84. Petition for Writ of Certiorari, supra note 9, at 9.

85. People for the American Way, Freedom of Information Act Request, Nov. 5, 2003, http://www.pfaw.org/pfaw/dfiles/file_482.pdf.

86. Dan Christensen, Feds Drop \$373,000 FOIA Search Fee Demand, Apr. 4, 2005, http://www.law.com/jsp/article.jsp?id=1112349912757. According to the DOJ attorney, "[M]any material witnesses were arrested, and in a lot of those cases they were just detained and never charged, . . [b]ut also in a lot of those cases, the government did ask for a proceeding . . to be sealed." Id. 


\section{Sealing Other Civil Matters}

In recent years, media plaintiff lawsuits have revealed that courts seal docket sheets in a variety of civil matters.$^{87}$ In perhaps the most prominent of these suits, the Hartford Courant and the Connecticut Law Tribune challenged a longstanding Connecticut state eourt practice of sealing certain docket sheets, as well as entire case files. ${ }^{88}$ In Iate 2002 , the two newspapers uncovered a dual-docketing policy in the Connecticut Judicial Department that even many of the state's judges did not know about. ${ }^{89}$ Certain litigants could conceal the very existence of cases in which they were involved (level I sealing); ${ }^{90}$ others were given complete secrecy except for disclosure of the captions of their cases and their docket numbers (level 2 sealing). ${ }^{91}$ In the former instance, court personnel were forbidden from disclosing any information regarding a case, including the docket number and case caption, and such cases were not allowed to appear on any calendars..$^{92}$ In the latter instance, entire case files were sealed from the press and the public, but court personnel could disclose a case's caption and docket number. ${ }^{93}$ It was unclear whether superior court

87. See, e.g., Hartford Courant Co. v. Pellegrino, 380 F.3d 83 (2d Cir. 2004); Globe Newspaper Co. v. Doe, 2000 Mass. Super. LEXIS 603 (2000); State ex rel. Cincinnati Post v. Court of Appeals, 604 N.E.2d 153 (Ohio 1992); see also West, supra note 42, at Al (reporting use of "Special Matters Confidential" docket within state supreme court in order to conceal cases involving attorney disability and trade sccrets).

88. Pellegrino, 380 F.3d at 85 . The plaintiffs discovered the dual-docketing system through conversations with family law judges and attomeys. See Thomas B. Scheffey, State Divorce Courts Quick to Cloak Cases, ConN. L. TriB., Dec. 2, 2002, at 1.

89. Pellegrino, 380 F.3d at 86; Eric Rich \& Dave Altimari, Elite Enjoy "Secret File" Lawsuits, HARTFord COURANT, Feb. 9, 2003, at Al ("With wide discretion and little accountability, judges have selcctively scaled divorce, paternity and other cases involving fellow judges, celebrities and wealthy CEOs that, for most people, would play out in full view of the public. ...); Scheffey, supra note 88, at 1 ("Depending on the attitude of the judge, important people can get the caption of their case rejiggered so their real names do not appear. ... [T] [Tey can have the public excluded from some or all court procecdings-or even have the case so super-secret that no docket number or history of motions and rulings is available."). The chief justice of the Connecticut Supreme Court, William J. Sullivan, would later testify before the Connecticut General Assembly regarding the origins of the dualdocketing practice:

The best $\mathbf{l}$ can determine is that this started somehow and it might have gone back as early as

the 70's where it became an unwritten rule that in those days there were 16 or 20 Superior

Court Judges who wcre really very, very powerful, much more powerful than the judges are

today .... [W] [Wen they fclt it was necessary, they would seal a file and just start it.

Pellegrino, 380 F.3d at 86 (citation omitted).

90. Pellegrino, 380 F.3d at 87 . Once the Connecticut judiciary began to revicw its sealing practices, officials dctermincd that 104 cases had becn classified as "level one" cases. $I$ d.

91. Id. The different levels of secrecy were described in a June 2000 memo written by the civil court manager of the Connecticut Judicial Department to trial court administrators and chief clerks. Id. The state's counsel asserted at oral argument that "thousands" of cascs were classified as "level 2" cascs. Id.

92. Id.

93. Pellegrino, 380 F.3d at 87. 
judges had, in any of the secret cases, issued sealing orders. ${ }^{94}$ As the plaintiffs noted, though, if any sealing orders had been issued, they were likely themselves concealed in the sealed files of the cases. ${ }^{95}$ The media plaintiffs sought an injunction requiring, on First Amendment grounds, disclosure of the sealed docket sheets. ${ }^{96}$

Relying on 'the public's and the press's qualified First Amendment right to attend judicial proceedings and to access certain judicial documents," the Second Circuit held that the media and public possess a qualified First Amendment right of access to docket sheets. ${ }^{97}$ According to the court, the right of the public and the press to attend civil and criminal proceedings "would be merely theoretical if the information provided by docket sheets were inaccessible." 98 The court also found compelling the lengthy history of public access to docket sheets in England and the United States. ${ }^{99}$

In response to the Second Circuit's decision, the Connecticut Judicial Branch unsealed more than 10,000 level 2 case files, ${ }^{100}$ and it released the docket numbers and party identities for most of the level 1 cases. ${ }^{101}$ Among the cases declassified from level 1 secrecy were a lawyer's and a bar applicant's discipline matters, a civil lawsuit brought against a court administrator, and prisoners' legal actions against their wardens. ${ }^{102}$ Most of the level 2 cases comprised divorce or family law matters involving state officials, judges, prominent attorneys, corporate officers, and celebrities, including Bruce Springsteen's saxophonist and a soap opera star. ${ }^{103}$

The above studies of habeas corpus and civil cases have illustrated that docket sealing compromises the integrity of the judicial system by creating the appearance of furtiveness, concealing valuable information from the public and the press, and establishing a secret court system for the privileged. The next Section focuses on docket sealing in criminal cases.

94. Id. at 86. A U.S. District Court judge who later reviewed the judicial sealing orders in fortyone of the level one cases stated in a hearing: "l did not see a [single] judicial order stating that the docket sheet should be sealed." Thomas B. Scheffey, Chatigny at Wit's End Over Super-Secret Files, ConN. L. TriB., Oct. 18, 2004, at 1.

95. Brief of Plaintiffs-Appellants at 4, Hartford Courant Co. v. Pellegrino, 380 F.3d 83 (2d Cir. 2004) (No. 03-9141).

96. Pellegrino, 380 F.3d at 85 .

97. Id. at 91

98. Id. at 93 .

99. Id.

100. Thomas B. Scheffey, Courts to Open I0,000 Sealed Files to Public, ConN. L. Tr1B., Sept. 27,2004 , at 1 .

101. Thomas B. Scheffey, Former "Level I" Cases Reveal Origins of Super-Secret Files, ConN.

L. TRIB., Apr. 25, 2005, at 1.

102. Id.

103. Rich \& Altimari, supra note 89 , at A1. Other level 2 cases involved actions against the state or against private businesses trying to protect their financial standing or image. Altimari, supra note 41 , at $\mathrm{Al}$. 
This practice not only restricts the public's access to information regarding the fairness of the criminal justice system, but it can also infringe upon defendants' constitutional rights.

\section{The Sealing of Criminal Dockets}

Despite the First Amendment's guarantee of a public right of access to criminal proceedings ${ }^{104}$ and the Sixth Amendment's guarantee of a criminal defendant's right to a public trial, ${ }^{105}$ courts still seal criminal docket sheets. ${ }^{106}$ Although Eleventh Circuit precedent bars "dual-docketing systems," until recently the Southern District of Florida maintained a secret docket for certain criminal cases. ${ }^{107}$ In United States $v$. Valenti, the Eleventh Circuit became the first circuit court to address whether a First Amendment right of access to docket sheets exists. The court held that the use of sealed dockets for criminal proceedings unconstitutionally infringed the public's and press' right of access to criminal proceedings. ${ }^{108}$ There, secret docketing concealed proceedings and filings in a government official's corruption trial. ${ }^{109}$ Noting that the sealed docket was "inconsistent with affording the various interests of the public and press meaningful access to criminal proceedings," the Eleventh Circuit held that the district court's maintenance of a "dual-docketing system" was impermissible in criminal cases. ${ }^{110}$

In spite of the Eleventh Circuit's holding in Valenti, until recently the Southern District of Florida sealed criminal proceedings, including their accompanying dockets, with the apparent goal of protecting codefendants who had accepted plea deals in high-profile drug-trafficking cases. ${ }^{111}$ The

104. Richmond Newspapers, lnc. v. Virginia, 448 U.S. 555 (1980).

105. U.S. Const. amend. V1.

106. See, e.g., United States v. Ochoa-Vasquez, 428 F.3d 1015 (11th Cir. 2005) (holding unconstitutional a system of dual docketing in a district court's criminal cases); United States v. Valenti, 987 F.2d 708, 715 (11th Cir. 1993) (same); In re State-Record Co., 1nc., 917 F.2d 124 (4th Cir. 1990) (per curium) (revcrsing the sealing of docket sheets in certain criminal matters because the ordcr requiring sealing was overbroad and violated the plaintiffs' First Amendment rights); see also Mitchell \& Burgess, supra note 2, at 4 (reporting that 18 percent of nearly 3,000 criminal cases wcre not docketed in Washington, D.C.'s federal district court); Gerard O'Neill \& Dick Lehr, State Stumbles in Pursuit of Political Corruption, Boston Globe, Dec. 10, 1989, at 1 (describing inability of reporters to obtain docket sheets for cases involving criminal prosecution of political corruption).

107. Ochoa-Vasquez, 428 F.3d at 1029-30.

108. United States v. Valenti, 987 F.2d 708, 715 (11th Cir. 1993). The scope of the public's right of access to criminal proceedings is discussed in detail in Part 11.A.2, infra.

109. Valenti, 987 F.2d at 715.

110. Id.

111. Ochoa-Vasquez, $428 \mathrm{~F} .3 \mathrm{~d}$ at 1027-28. The codefendants were indicted as part of an invcstigation into Colombian drug trafficking called Operation Millennium. Id. at 1017. Several codefendants prosecuted in connection with Operation Millennium agreed to cooperate with the government in exchange for plea bargains. Id. at 1027-28. Seeking to protect these defendants and other informants used in Operation Millennium, the parties agreed to seal criminal proceedings, rccords, and entire criminal cases. $I d$. 
district court removed the codefendants' cases from the public docket to conceal the codefendants' identities once they had cooperated with the government. ${ }^{112}$ In United States $v$. Ochoa-Vasquez, Ochoa, a convicted drug trafficker linked to the Medellin cartel, sought to unseal the cases of several codefendants to obtain evidence for his own defense. ${ }^{113}$ In drugtrafficking cases involving Ochoa's codefendants, magistrate judges had kept orders and transcripts of plea-bargain proceedings from the public docket, directing "that they be held in the vault and not docketed."114

Ochoa had sought to admit evidence at his drug conspiracy trial about an illegal extortion scheme called the Rehabilitation Program of Narcotics Traffickers. ${ }^{115}$ According to Ochoa, renegade DEA informants "solicited drug traffickers to surrender to the U.S. government by promising to arrange phony cooperation deals." 116 The traffickers "could then join the program by paying money and surrendering drugs to U.S. authorities through staged drug busts. The confiscated drugs would then be attributed to other traffickers." 117 The recruits of the scheme "were told that they would receive credit for their "cooperation""118 in the form of "favorable plea bargains from U.S. prosecutors." 119

To prove the existence of the alleged conspiracy, Ochoa sought access to court documents in the case of alleged program participant and drug trafficker Nicholas Bergonzoli. ${ }^{120}$ Ochoa planned to call Bergonzoli as a witness, because Bergonzoli allegedly had encouraged Ochoa to join the program and told Ochoa of his participation in staged drug busts "and the resulting leniency he received." 121 However, the government convicted, sentenced, and imprisoned Bergonzoli in total secrecy, hindering Ochoa's efforts to build his case. ${ }^{122}$ The docket number for Bergonzoli's case was missing from the public docket at the federal courthouse, ${ }^{123}$ and Ochoa later discovered that the court had sealed many of the documents in Bergonzoli's. ${ }^{124}$

112. Id. at $1027-28$.

113. Id. at 1028. One of Ochoa's codefendants, whose case was maintained on a secret docket, "was convicted, sentenced, and imprisoned ... in total secrecy" to protect his safety. Dan Christensen, Court Secrets, DaIly Bus. Rev., May 9, 2003, at Al.

114. Ochoa-Vasquez, 428 F.3d at 1028. According to one of Ochoa's attomeys, "[w]hen you put the case number in the computer system, it came up empty... And the clerk's office, when we approached them, refused to acknowledge it existed." De Vise, supra note 60.

115. Ochoa-Vasquez, 428 F.3d at 1022.

116. Id.

117. Id.

118. Id.

119. Id.

120. Id. at 1022-23.

121. Ochoa-Vasquez, 428 F.3d at 1023.

122. Mitchell \& Burgess, supra note 2, at 4.

123. Id.

124. Ochoa-Vasquez, 428 F.3d at 1023. 
By the time Ochoa's case reached the Eleventh Circuit, the district court had voluntarily unsealed the dockets at issue, making Ochoa's motion to unseal the docket moot. ${ }^{125}$ Despite this, the appeals court rebuked the district court by reminding it that "it cannot employ the secret docketing procedures that we[re] explicitly found unconstitutional in Valenti." ${ }^{126}$ A federal district court judge who sealed one of the drugtrafficking cases later vowed never to do it again. ${ }^{127}$

The rest of this Comment examines the history of the public's right of access to criminal and civil proceedings, and how this history supports a First Amendment right of access to dockets. The examples of secret docketing laid out in Part I are then used to explore the potential scope of a First Amendment right of access to dockets.

II

\section{The Constitutional Right of Access to Dockets}

Part II of this Comment first examines the history of common law and First Amendment access to governmental institutions, focusing on the courts. It reviews the right of access to government-controlled information in general, as well as the right of access to court proceedings and documents in particular. Although a common-law right of access to court documents, including docket sheets, exists, this Comment argues that a First Amendment right of access to docket sheets would better protect the public's interests. The common-law presumption favoring access is easier to rebut and affords less substantive protection to the public's right of access than could the First Amendment. The Comment then interprets Supreme Court jurisprudence to develop three theories supporting a First Amendment right of access to dockets: (I) a right of access to dockets is a necessary corollary to the right of access to judicial proceedings and documents; (2) the Supreme Court's two-prong "experience and Iogic" test supports a public right of access; and (3) access to dockets must be given First Amendment protection because the public must know the business of the courts to effectively speak and publish about the judiciary.

\section{A. Development of First Amendment Access Doctrine}

This Section examines the evolution of First Amendment access to govemment information and proceedings, from the Supreme Court's initial unwillingness to grant the media access to prisons to its eventual

125. Id. at 1029-30.

126. Id. at 1030 .

127. Julie Kay, Federal Judges Slammed for Secret Docketing, 28 NaT'L L. J. 21 (2005). In response to the Eleventh Circuit's reprimand of the district court, U.S. District Judge Patricia A. Seitz stated, "Judges are not gods. Like any human being, we make mistakes. When your mistake is pointed out, you reconsider your action and you promptly make a correction." $I d$. 
recognition of a First Amendment right to attend criminal proceedings. The Comment then moves from addressing judicial proceedings to discussing the right of access to judicial documents, with an emphasis on the distinction between the common-law and First Amendment rights of access to such documents.

\section{Right of Access to Government Information}

Although the Supreme Court recognizes that the First Amendment "prohibit[s] government from limiting the stock of information from which members of the public may draw," 28 the Court has not interpreted this prohibition as an affirmative right of individuals to compel the government to provide information. ${ }^{129}$ This Comment argues in Part II.B.3, infra, that (1) an affirmative First Amendment right of access exists to the information provided by docket sheets (a form of government information); and (2) this right inheres in the Amendment's guarantees of freedom of speech and press. As a result, it is necessary here to examine the Court's jurisprudence regarding First Amendment access to information within the government's control.

The Court's most influential cases examining whether the First Amendment rights to speak and publish include a First Amendment right of access to government information involve access to prisons. In Pell v. Procunier ${ }^{130}$ and Saxbe $v$. Washington Post, ${ }^{131}$ the Court rejected journalists' claims to a right to interview specific inmates in prisons. Although the Court noted that "the First and Fourteenth Amendments ... protect the right of the public to receive such information and ideas as are published," 132 it ultimately concluded that "[t]he right to speak and publish does not carry with it the unrestrained right to gather information." 133 Four years later, the Court again upheld restrictions on the media's access to prisons and inmates. ${ }^{134}$ In Houchins $v$. KQED, Inc., the plurality opinion, written by Chief Justice Burger, asserted that the First Amendment does not "mandate[] a right of access to government information or sources of information within the government's control. ..."135 Thus, at least in the prison context, the Court held that the First Amendment right to speak and publish does not confer a First Amendment right to know.

128. Richmond Newspapers, Inc. v. Virginia, 448 U.S. 555, 576 (1980).

129. Donald lively et al, First Amendment law: Cases, Comparative Perspectives, and Dialogues 544 (2003).

130. 417 U.S. $817(1974)$.

13I. 4 II U.S. 843 (1974).

132. Pell, 4 I 7 U.S. at 832 .

133. Id. at 834 n.9 (quoting Zemel v. Rusk, 381 U.S. 1, I6-17 (1965)).

134. Houchins v. KQED, Inc., 438 U.S. 1 (1978).

135. Id. at I5. 


\section{Right of Access to Judicial Proceedings}

The Court's unwillingness to recognize a First Amendment right of access to government institutions and information in the prison cases took a dramatic turn in Richmond Newspapers $v$. Virginia. There, the Court held that the press and the public have a First Amendment right to attend criminal trials. ${ }^{136}$ Chief Justice Burger's plurality opinion emphasized the history of public access to criminal trials, stating that, "throughout its evolution, the trial has been open to all who cared to observe." 137 In addition, the Chief Justice noted that the openness of criminal trials improved the functioning of the judicial system because "it gave assurance that the proceedings were conducted fairly to all concerned, and it discouraged perjury, the misconduct of participants, and decisions based on secret bias or partiality." 138

In his concurrence, Justice Brennan also acknowledged the importance of history, noting that a public access claim has "special force" if it derives from tradition and has gained the "favorable judgment of experience." 139 But he placed an even greater emphasis on the "structural role" that the First Amendment plays in "securing and fostering our republican system of self-government."140 According to Brennan, selfgovernance requires robust and uninhibited debate on matters of public concern, and access to criminal proceedings ensures that this debate is informed. ${ }^{141}$ Thus, the plurality and the concurrence used a similar twoprong test to determine whether access warrants First Amendment protection: the access sought must have some basis in history, and it must enhance the functioning of the governmental process at issue. ${ }^{142}$.

In his majority opinion in Globe Newspaper Co. v. Superior Court, ${ }^{143}$ Brennan reiterated Richmond Newspapers' "two helpful principles"144 for

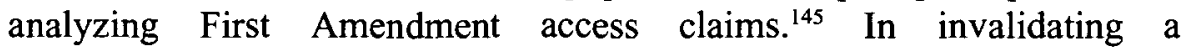
Massachusetts law requiring the closure of rape trials during the testimony of minor victims, Brennan again noted the long history of public access to criminal trials and the structural role that open trials serve in enhancing the

\footnotetext{
136. Richmond Newspapers, lnc. v. Virginia, 448 U.S. 555 (1980).

137. Id. at 564 .

138. Id. at 569 .

139. Id. at 589 (Brennan, J., concurring).

140. Id. at 587 (Brennan, J., concurring) (emphasis removed).

141. Id.

142. See Richmond Newspapers, 448 U.S. at 597-98 ("[R]esolution of First Amendment public access claims in individual cases must be strongly influenced by the weight of historical practice and by an assessment of the specific structural value of public access in the circumstances.") (Brennan, J., concurring).

143. 457 U.S. $596(1982)$

144. Richmond Newspapers, 448 U.S. at 589.

145. Globe Newspaper Co. v. Superior Court, 457 U.S. 596, 605-06 (1982).
} 
judicial process. ${ }^{146}$ Expanding upon the structural component of the Richmond Newspapers test, he explained that the Court protects access to criminal trials because access "permits the public to participate in and serve as a check upon the judicial process - an essential component in our structure of self-government."147

The Court continued to apply the two-prong "experience and logic"148 test in later cases involving pretrial criminal proceedings, holding that there is a right of access to voir dire examinations ${ }^{149}$ and preliminary hearings. ${ }^{150}$ Further, the Court dictated the standard for closure of court proceedings, stating that such closure can be ordered only if: (1) closure is essential to preserve higher values than the public's right of access; (2) a "substantial probability" exists that, in the absence of closure, those higher values would be harmed; and (3) no reasonable alternatives to closure exist that would adequately protect those values. ${ }^{151}$ In making this determination, a court inust make specific findings on the record such that "a reviewing court can determine whether the closure order was properly entered." 152

Despite expanding the right of access to criminal proceedings, the Court did not indicate whether the right extended to civil trials. ${ }^{153}$ Still, using the reasoning employed in Richmond Newspapers and its progeny, several circuit courts have held that a right of access exists to civil proceedings. ${ }^{154}$ In Brown \& Williamson Tobacco Corp. v. F.T.C., ${ }^{155}$ for example, the Sixth Circuit held that the policy considerations cited in Richmond Newspapers compelled access in civil as well as criminal cases:

The resolution of private disputes frequently involves issues and remedies affecting third parties or the general public. The community catharsis, which can only occur if the public can watch

146. Id. at $605-06$.

147. Id. at 606 .

148. Press-Enter. II, 478 U.S. 1,9 (1986).

149. Press-Enter. Co. v. Superior Court (Press-Enter. I), 464 U.S. 501 (1984).

150. Press-Enter. $I I, 478$ U.S. at 13.

151. Id. at 13-14.

152. Press Enter. 1, 464 U.S. at 510.

153. The Court has noted in dicta that civil trials, like criminal trials, have historically been open. See Richmond Newspapers, 448 U.S. at 580 n.17 (plurality opinion of Burger, C.J.) ("Whether the public has a right to attend trials of civil cases is a question not raised by this case, but we note that historically both civil and criminal trials have been presumptively open.").

154. See, e.g., Westmoreland v. CBS, 752 F.2d 16, 23 (2d Cir. 1984) (holding that public and press possess a First Amendment right of access to civil proceedings); Publicker Indus. Inc. v. Cohen, 733 F.2d 1059, 1061 (3d Cir. 1984) (samc); Brown \& Williamson Tobacco Corp v. Fed. Trade Comm'n, 710 F.2d 1165, 1180-81 (6th Cir. 1983) (recognizing a qualified right of access to civil proceedings); Newman v. Graddick, 696 F.2d 796, 801 (11th Cir. 1983) (holding that civil proceedings that pertain to conditions of imprisonment are presumptively open to the public); see also In re lowa Freedom of lnfo. Council, 724 F.2d 658, 661-63 (8th Cir. 1983) (holding that the public has a First Amendment right to attend contempt proceedings).

155. 710 F.2d 1165 (6th Cir.1983). 
and participate, is also necessary in civil cases. Civil cases frequently involve issues crucial to the public-for example, discrimination, voting rights, antitrust issues, government regulation, bankruptcy, etc. The concern ... that secrecy eliminates one of the important checks on the integrity of the system applies no differently in a civil setting. ${ }^{156}$

Thus, although the Supreme Court has not determined the contours of the right to attend civil trials or whether such a right exists, several courts have transferred the Court's reasoning in access cases to the civil context.

\section{Right of Access to Court Documents}

The Supreme Court has held that the common law presumes access to judicial records and a right to inspect and copy those records. ${ }^{157}$ But the Court also noted the difficulties in defining these rights. ${ }^{158}$ Beyond common law, some courts derived a First Amendment right of access to court documents from the First Amendment right of access to judicial proceedings. ${ }^{159}$ The courts reasoned that without access to court documents, the public would not fully understand the proceedings and would not be able to check the system. ${ }^{160}$ Courts recognized that people may not have the time or the means to observe judicial proceedings, leaving them to rely on the transcripts of proceedings instead of attending in person. ${ }^{161}$ "It would be an odd result indeed were we to declare that our courtrooms must be open, but that transcripts of the proceedings occurring there may be closed," explained the Third Circuit. "For what exists of the right of access if it extends only to those who can squeeze through the door?"162

A court's decision to rely on the First Amendment instead of common law affects the showing a party must make to rebut the presumption of access. If the First Amendment protects the right of access, any denial of access must be justified by a compelling interest and must be narrowly

156. Id. at $\mathbf{1 1 7 9 .}$

157. Nixon v. Warner Commc'ns, lnc., 435 U.S. 589 (1978) (holding that common-law right of access to judicial records did not require the release of tape recordings that had been introduced at a criminal trial). Nixon was decided before the Court held that there is a First Amendment right to attend criminal trials, and the Court conceded that even the common-law right of access "ha[s] not been delineated with any precision." Id. at 597.

158. Id. at 598-99.

159. See, e.g., In re Providence Journal Co., 293 F.3d 1, 10-13 (1st Cir. 2002); Phoenix Newspapers v. U.S. Dist. Court, 156 F.3d 940, 948 (9th Cir. 1998); United States v. Antar, 38 F.3d 1348, 1359-60 (3d Cir. 1994); Grove Fresh Distrib., 1nc. v. Everfresh Juice Co., 24 F.3d 893, 897 (7th Cir. 1994); Globe Newspapcr Co. v. Pokaski, 868 F.2d 497, 505 (1st Cir. 1989); In re Search Warrant, 855 F.2d 569, 573 (8th Cir. 1988).

160. Globe Newspaper, 868 F.2d at 502 (citing In re Globe Newspaper Co., 729 F.2d 47, 52 (1st Cir. 1984)).

161. See United States v. Criden, 648 F.2d 814, 822 (3d Cir. 1981).

162. Antar, 38 F.3d at 1360 . 
tailored to serve that interest. ${ }^{163}$ In addressing a First Amendment right-ofaccess claim, an appellate court's standard of review is substantially less deferential than the abuse-of-discretion standard. ${ }^{164}$ This broader review includes independent consideration of the trial court's order and the factual findings inferred from the evidence before it. ${ }^{165}$

But the common-law presumption of access can be overcome if "countervailing interests heavily outweigh the public interests in access."166 The trial court may weigh "the interests advanced by the parties in light of the public interests and the duty of the courts." ${ }^{167}$ Courts even held that the access decision is best left to the trial court. ${ }^{168}$ Courts only review a trial court's denial of access to documents for abuse of discretion. ${ }^{169}$ Thus, the common law does not protect the interests of the press and public as much as the First Amendment does. ${ }^{170}$

\section{B. The Arguments for a First Amendment Right of Access to Docket Sheets}

Relatively few courts have passed on the public's First Amendment right of access to docket sheets, ${ }^{171}$ but most of those addressing the issue found that such a right exists. ${ }^{172}$ A First Amendment right of access to docket sheets may be based on three theories: (1) a right of access to docket sheets is a necessary corollary to the right of access to judicial proceedings and documents; (2) the Supreme Court's two-prong experience-and-logic test supports a public right of access to dockets; (3) knowing the business of the courts vis-à-vis dockets is so essential to the public's ability to speak and publish on matters regarding the courts that it must be given First Amendment protection. The first two theories are relatively uncontroversial, and the few courts that have examined docket-sheet access employed them to find a First Amendment right of access. The third theory has received little support in First

163. See Rushford v. New Yorker Magazine Inc., 846 F.2d 249, 253 (4th Cir. 1988) (citing PressEnter. Co. v. Superior Court, 464 U.S. 50I, 510 (1984)).

I64. In re Capital Cities/ABC, Inc.'s Application for Access to Sealed Transcripts, 913 F.2d 89, 92 (3d Cir. 1990)

165. Id. at 92 (citing Bose Corp. v. Consumers Union, 466 U.S. 485, 499 (1984)).

166. Rushford, 846 F.2d at 253.

167. Id. (citing Nixon v. Warncr Commc'ns, Inc., 435 U.S. 589, 602 (1978)).

168. See Nixon, 435 U.S. at 599.

169. Rushford, 846 F.2d at 253 (citing Nixon, 435 U.S. at 597-99).

170. $I d$.

171. In a recent case, the Second Circuit noted that it had found only one dccision denying a First Amcndment right to docket sheets. Pellegrino, 380 F.3d 83 at 96 . The decision, In re Sealed Case, 199 F.3d 522 (D.C. Cir. 2000), involved grand jury proceedings, which are traditionally entitled to a strong presumption of secrecy.

172. See, e.g., United States v. Ochoa-Vasquez, 428 F.3d 1015 (1 Ith Cir. 2005); Pellegrino, 380 F.3d at 96; United States v. Valenti, 987 F.2d 708, 715 (1 Ith Cir. 1993); In re Search Warrant, 855 F.2d 569, 575 (8th Cir. 1988); Globe Newspaper Co. v. Fenton, 819 F. Supp. 89, 91 (D. Mass. 1993). 
Amendment access jurisprudence, but it provides the most dynamic argument for an expansive right of access to docket sheets.

\section{Access to Docket Sheets as a Prerequisite to Established First Amendment Rights}

Courts have held that a right of access to docket sheets is a necessary antecedent to the right to attend judicial proceedings and to inspect and copy court records. ${ }^{173}$ As noted, the Supreme Court held that a First Amendment right of access to criminal proceedings exists, ${ }^{174}$ and several circuit courts established a right of access to civil proceedings and court documents. ${ }^{175}$ Members of the public cannot exercise these rights of access, however, if they do not know that a particular document or proceeding even exists. The press and public rely on docket sheets to provide notice of the scheduling of a proceeding or the filing of a document. ${ }^{176}$ Denying access to docket sheets effectively results in a denial of the right to attend judicial proceedings or to view court records. In United States v. Valenti, for example, the Eleventh Circuit held that a secret docketing system was unconstitutional because it precluded the public and press from exercising their constitutional right of access to transcripts of criminal proceedings in a government corruption prosecution. ${ }^{177}$

The argument for an "antecedent" right of access to docket sheets, while compelling, cannot support a First Amendment right of access in all cases. The argument makes sense in the criminal context, where most courts accept that the public can attend proceedings and view court documents. Because the right to attend criminal trials is well defined, it is easy to argue that individuals must have access to the document that tells them when a criminal trial will take place.

Access to civil cases and documents is not as well defined. Take, for example, jurisdictions in which courts have narrowly construed the right of access to civil court proceedings or documents, or have not addressed the issue at all. ${ }^{178}$ In M.K.B. v. Warden, the right of access to docket sheets

173. See, e.g., Pellegrino, 380 F.3d at 93 ("[T]he ability of the public and press to attend civil and criminal cases would be merely theoretical if the information provided by docket sheets were inaccessible."); United States v. Valenti, 987 F.2d 708, 715 (11th Cir. 1993) ("[The district court's] maintenance of a dual-docketing system is an unconstitutional infringement on the public and press's qualified right of access to criminal proceedings.").

174. Richmond Newspapers, lnc. v. Virginia, 448 U.S. 555 (1980).

175. See Parts ll.A.2 and 11.A.3, supra.

176. Brief Amici Curiae in Support of Plaintiffs-Appellants at 15, Hartford Courant Co. v. Pellegrino, 380 F.3d 83, 92 (2d Cir. 2004) (No. 03-9141) ("[R]eview of court docket sheets has always been the primary method by which amici and their reporters have gathered information about court cases.").

177. Valenti, 987 F.2d at 715.

178. See Eugene Cerruti, "Dancing in the Courthouse": The First Amendment Right of Access Opens a New Round, 29 U. RiCH. L. REV. 237, 269-70 (1995) ("Different courts have almost arbitrarily 
could not be derived from the public's right to attend habeas corpus proceedings, because no such right presently exists in the Eleventh Circuit. ${ }^{179}$ In fact, even though habeas proceedings are closely tied to criminal matters, the public's right of access to these proceedings is not clearly established in most jurisdictions. Because there is not a widely accepted right to attend habeas proceedings, members of the public may have difficulty arguing that they must have access to habeas docket sheets to attend these proceedings. Thus, claimants are on shaky ground where jurisdictions have eliminated rights of access or limited those rights. ${ }^{180}$ Even in jurisdictions where courts have held that a right of access to civil trials is guaranteed, most civil cases do not make it to trial. ${ }^{181}$ As a result, the right to view docket sheets cannot be based solely on the right to attend civil trials because in many cases there will be no trials.

Given the uncertainty of the rights to attend civil proceedings and view civil court documents, using other access rights may not be a good way to derive a right of access to docket sheets. The important information in a docket, standing alone, may be worthy of First Amendment protection. That argument is addressed in Part II.B.3.

\section{Access to Docket Sheets and the Two-Prong Experience and Logic Test}

Rather than deriving the right of access to docket sheets from other First Amendment rights, such as the right to attend criminal proceedings or to inspect transcripts from such proceedings, some courts have taken a more direct route by holding that access to docket sheets satisfies the Supreme Court's two-prong "experience and logic" test. ${ }^{182}$ First, as noted in Part I.A, docket sheets traditionally have been open to the public, satisfying the requirement that the access claim be supported by "historical practice."183

relied upon different bodies of law to resolve common issues of access, often arriving at different results.").

179. The closest any circuit court has come to holding that a right of access to habeas corpus proceedings exists was in Newman v. Graddick, 696 F.2d 796 (11th Cir. 1983), in which the Eleventh Circuit held that civil proceedings that "pertain to the release or incarceration of prisoners and the conditions of their confinement" are "presumptively open to the press and public."

180. See Cerruti, supra note 178 , at $270-71$ ("[A] claimant who is constitutionally entitled to access to information presented at a proceeding, yet denied access to that proceeding, may nonetheless be denied access to the transcript of that information because a lesser standard of closure is applied to documents.")

181. See Stephen C. Yeazell, The Misunderstood Consequences of Modern Civil Process, 1994 WIS. L. REV. 631,633 (noting that in 1990, approximately $4 \%$ of all filed cases in federal court resulted in trials).

182. See, e.g., Pellegrino, 380 F.3d at 94; Globe Newspaper Co. v. Fenton, 819 F. Supp. 89, 91 (D. Mass. 1993).

183. Richmond Newspapers, Inc. v. Virginia, 448 U.S. 555, at 597 (Brennan, J., concurring). 
Second, courts find that access to docket sheets enhances the appearance of fairness in the judicial system and helps the public monitor the system, ${ }^{184}$ satisfying the requirement that the access sought have the "specific structural value" of enhancing the functioning of the government process at issue. ${ }^{185}$ Open dockets enhance the functioning of the judicial system because they allow the public to examine judges' caseloads for conflicts of interest. ${ }^{186}$ Members of the public can find conflicts of interest by examining docket sheets to determine whether a judge, as an attorney, ever represented an entity that is a party to a case over which she currently presides. Reporters from the New York Times, for example, discovered that a judge presiding over a case involving the Monsanto Company had previously represented the company in a case that covered some of the same issues. ${ }^{187}$ The reporters discovered the conflict of interest because the attorney-turned-judge previously had been listed on a federal court docket as a lawyer representing Monsanto. ${ }^{188}$ Additionally, in federal district courts docket numbers often contain judges' initials, enabling the public to examine cases based on which judge presided over them. As a result, docket numbers aid advocates in determining whether a particular judge frequently grants requests to seal files or proceedings (assuming that those orders are docketed) or whether a judge regularly grants or denies motions for summary judgment in a particular type of case, such as Section 1983 actions or employment-discrimination suits.

Perhaps most importantly, dockets provide notice of scheduled hearings and trials. This enables the public to attend judicial proceedings, and thus check the system by observing the conduct of judges, courtroom personnel, and attorneys. ${ }^{189}$ ln the criminal justice system, docketing enables the public to keep track of undue delay in the scheduling of criminal proceedings ${ }^{190}$ and to monitor the performance of prosecutors. ${ }^{191}$ Docketing is especially crucial to enhancing public scrutiny of cases in which parties move to close the proceedings or seal court documents. Docketing motions to seal court documents puts the public on notice and

184. See Pellegrino, 380 F.3d at 95-96. As noted by the attorney who represented Jane Welch in her divorce from former General Electric CEO Jack Welch, "It . . . inspires confidence in the judiciary if files aren't sealed. ... The average person won't feel there are two systems of justice-one for the rich people who can get their cases kept secret and one for everybody else." Rich \& Altimari, supra note 89 , at $\mathrm{Al}$.

185. See Richmond Newspapers, 448 U.S. at 597-98 (Brennan, J., concurring).

186. See Pellegrino, 380 F.3d at 95 (citing David Barboza, Bias Issue Arises for Monsanto Case Judge, N.Y. Times, Jan. 9, 2004, at C1).

187. Barboza, supra note 186.

188. Id.

189. Globe Newspaper Co. v. Fenton, 819 F. Supp. 89, 96 (D. Mass. 1993).

190. See John Aloysius Farrell, Half-Day Justice: Despite Caseload, Many Judges Work Short Day, Boston Globe, Sept. 23, 1990, at Al.

191. See Gerard O'Neill \& Dick Lehr, State Stumbles in Pursuit of Political Corruption, Boston Globe, Dec. 10, 1989, at 1. 
affords the public an opportunity to object to the motion. ${ }^{192}$ With both sides of the issue adequately represented, the court is able to make an informed ruling on whether the proceedings or documents should be sealed.

In most cases, then, access to dockets will fit squarely within the two prongs of the experience-and-logic test. However, justifying a First Amendment right to open dockets on this test alone is not wholly satisfying. Although the test recognizes the importance of public monitoring of the judicial system, it does not equally recognize the public's interest in simply knowing what is going on in the courts. As a result, this Comment argues that the First Amendment right of access to docket sheets should be based both on the values recognized by the experience-and-logic test as well as docket sheets' facilitation of the public's ability to speak and publish information about court proceedings.

Under the Richmond Newspapers test, the right of access is grounded primarily in terms of the benefits that access will bring to the functioning of the system, and secondarily in terms of benefits to the public. Ordinarily, this distinction would not seem problematic, particularly in civil cases, because promoting efficient dispute resolution is a fundamental purpose of the courts. ${ }^{193}$ Arguably, providing citizens with information about proceedings that have public significance is a secondary purpose of the courts. ${ }^{194}$ But the function of docket sheets as a gateway to judicial proceedings is so essential to the public's ability to discuss matters involving the courts that it should be recognized as having importance equal to its ability to improve the functioning of the courts. The Iogic-andexperience test is not designed to take into account the damage done to the public's ability to freely comment on the courts' business when every detail of a proceeding-including its very existence-is concealed. In Hartford Courant Company v. Pellegrino, for example, the Second Circuit applied the test and held that the First Amendment right of access to docket sheets comes from the long history of such access and the ability of such access to enhance the fairness of the judicial system. ${ }^{195}$ The court did not address, however, the likelihood that Connecticut's use of secret dockets barred the press and the public from speaking out and publishing on matters of public significance. Such matters included prisoners' legal

192. In re Search Warrant, 855 F.2d 569, 575 (8th Cir. 1988).

193. Arthur R. Miller, Confidentiality, Protective Orders, and Public Access to the Courts, 105 HaRv. L. Rev. 427, 490 (1991); Richard L. Marcus, The Discovery Confidentiality Controversy, 1991 U. ILL. L. REv. 457, 468-70 (I991).

194. Miller, supra note 193, at 490.

195. 380 F.3d 83, 95-96 (2d Cir. 2004). 
actions against their wardens, ${ }^{196}$ a child abduction case, ${ }^{197}$ and sexual abuse cases brought against clergy. ${ }^{198}$

Certainly, the values that the logic-and-experience test recognizes provide valuable guideposts in analyzing whether a court proceeding or document should be open. However, to adequately recognize the impact that the sealing of dockets has on the public's right to speak and publish, the logic-and-experience test should be supplemented by a theory that examines how docket sheet access contributes to informed discourse.

In order to more fully ground the right, the rest of this Part argues that a First Amendment right of access to docket sheets should derive directly from the public's right to know, discuss, and publish information regarding the business of the courts.

\section{Access to Docket Sheets Under a "Right to Know" Theory}

As noted in Part 1I.A, the Supreme Court has not recognized a widespread, affirmative First Amendment right of access to information under the government's control. ${ }^{199}$ Nevertheless, in First Amendment access cases, the Court repeatedly recognizes that a major purpose of the Amendment is to protect the informed discussion of governmental affairs. ${ }^{200}$ According to the Court, access to criminal proceedings "serves to ensure that the individual citizen can effectively participate in and contribute to our republican system of self-government,"201 Such access enhances self-government because it "assur[es] freedom of communication on matters relating to the functioning of government" ${ }^{\$ 202}$ and enables the

196. Scheffey, supra note 101 , at 1 .

197. Id.

198. See generally Rosado v. Bridgeport Roman Catholic Diocesan Corp., 884 A.2d 981 (Conn. 2005) (recounting newspapers' challenge of court orders that sealed documents and dockets in sexual abuse cases filed against diocese); Rich \& Altimari, supra note 89 (noting that civil case involving sexual abuse charges against priest was sealed through state's secret docketing system).

199. See Houchins v. KQED, Inc., 438 U.S. 1, 15 (1978); see also DAvid M. O'BRIEN, ThE Public's Right to Know: The Supreme Court And The First Amendment 1 (1981) ("Neither the Constitution nor the Bill of Rights expressly guarantees the public a right to know, yet an impressive amount of litigation aims at vindicating that right as implicit in the First Amendment.").

200. See, e.g., Globe Newspaper Co. v. Superior Court, 457 U.S. 596, 604-05 (1982) ("[T]o the extent that the First Amendment embraces a right of access to criminal trials, it is to ensure that th[e] constitutionally protccted 'discussion of governmental affairs' is an informed one." (quoting Mills v. Alabama, 384 U.S. 214, 218 (1966)); see also Emerson, supra note 14 ((describing a "right to know" government information as implicit in the First Amendment's guarantee of freedom of expression); Daniel A. Farber, Free Speech Without Romance: Public Choice and the First Amendment, 105 HaRv. L. REv. 554, 556-57 (describing information as a public good, and noting that " $\mathrm{t}]$ he First Amcndment is based on the belief that people will make better decisions if they are more fully informed."); Richard A. Posner, Pragmatism Versus Purposivism in First Amendment Analysis, 54 Stan. L. Rev. 737, 743 (2002) (noting that "a democratic political system ... cannot prosper without freedom of inquiry.").

201. Id. at 604 .

202. Richmond Newspapers, 1nc. v. Virginia, 448 U.S. 555, 575 (1980). 
public to "serve as a check upon the judicial process." ${ }^{203}$ Although the Constitution does not affirmatively grant the public a right of access to court proceedings such as criminal trials and voir dire examinations, the Court recognizes that such a right inheres in the First Amendment's guarantees of speech and press. ${ }^{204}$ This Part similarly argues that the First Amendment right of access to docket sheets inheres in the First Amendment's guarantees of freedom of speech and press. Because sealing docket sheets dramatically constrains the public's ability to speak or publish information about the judiciary, it infringes First Amendment rights.

Citizens cannot participate in an informed discussion about the laws that govern them if the judiciary interprets such laws in complete secrecy. In order to meaningfully discuss and publish information about recently decided cases, the public must, at a minimum, be able to determine what cases the courts have adjudicated. Sealing docket sheets prohibits the public from ascertaining this basic information. For instance, when courts hide immigrant-detention cases from public view, citizens cannot write an investigative journalism piece, submit an amicus curiae brief, or organize a public protest regarding such cases. In United States v. Ochoa-Vasquez, reporters could not independently investigate Ochoa's allegations of government corruption because no news organization knew his case existed during his trial. ${ }^{205}$ Access to docket sheets thus deserves heightened protection because without access the public cannot discuss and publish information surrounding the actions of the judiciary, "a coordinate branch of government."206

Some argue that " $[\mathrm{t}]$ he traditional model of civil adjudication in this country envisions private parties bringing a private dispute to a. dispassionate arbiter,"207 and the "public access to information produced in litigation has always been a secondary benefit - a side effect-of civil adjudication. $" 208$ However, some civil cases produce information that is too valuable to the public interest to be classified as merely a "secondary benefit." The outcomes of civil cases "impose official and practical consequences upon members of society at large." 209 In M.K.B. v. Warden, for example, the facts of Mohamed Bellahouel's habeas proceedings "[could have made] a significant contribution to the national debate about

203. Globe Newspaper Co., 457 U.S. at 606.

204. Richmond Newspapers, 448 U.S. at 579.

205. See Mitchell \& Burgess, supra note 2, at 4.

206. Richmond Newspapers, 448 U.S. at 595 (Brennan, J., concurring).

207. Arthur R. Miller, Confidentiality, Protective Orders, and Public Access to the Courts, 105

HARv. L. REv. 427, 431 (1991); see also Richard L. Marcus, The Discovery Confidentiality

Controversy, 1991 U. 1LL. L. REv. 457, 469-70 (1991).

208. Miller, supra note 207, at 431 .

209. Richmond Newspapers, 448 U.S. at 595 (Brennan, J., concurring). 
the detention and treatment of Middle Eastern persons." ${ }^{10}$ Similarly, cases involving "discrimination, voting rights, antitrust issues, government regulation, [] bankruptcy," and myriad other issues of public interest have significant effects that extend beyond the parties to the action. ${ }^{211}$ Thus, judges "are not mere umpires, but, in their own sphere, lawmakers."212 Given the judiciary's immense power to shape the law, completely hiding the existence of cases offends self-government because it restricts the public's ability to have complete and informed discussions about how officials use this power. The public's interest in freely criticizing the judiciary's exercise of its "lawmaking" authority is so compelling that courts must give First Amendment protection to docket access-the keystone to this knowledge.

The "right to know" argument in favor of public access to docket sheets fails to satisfy some because of its limited scope. If public speech on the judicial process is so important, one might argue, why does the First Amendment right of access not extend to all court documents? Indeed, in many instances, the information on docket sheets may be meager and will contribute little to a meaningful discourse about the exercise of judicial authority, whereas access to pleadings would substantially further such discourse. However, the fact that docket sheets contain only minimal information actually supports a limited right of access. Unlike granting the public unfettered access to pleadings, public access to docket sheets is unlikely to expose trade secrets, financial assets, or intimate details about an individual's personal life. While the information provided by docket sheets may not bc as useful as the case filings themselves, public access to docket sheets does not pose the same harm threatened by widespread access to pleadings. Moreover, the limited information contained within docket sheets is an essential first step to permitting members of the public or press to investigate more thoroughly those issues that interest them.

Interpreting the First Amendment to provide for a right of access to docket sheets will vindicate the public discourse values the Amendment was designed to protect, but determining the scope of the right will likely prove controversial. The next Part discusses what docket sheet information must be made accessible under a First Amendment right of access to dockets, and it examines potential exceptions to this right.

210. See Petition for Writ of Certiorari, supra note 9, at 25.

211. See Brown \& Williamson Tobacco Corp v. Fed. Trade Comm'n, 710 F.2d 1165, 1179 (6th Cir. 1983).

212. Richmond Newspapers, 448 U.S. at 595 (Brennan, J., concurring). 


\section{III}

\section{The SCOPE OF THE Right of AcCess}

\section{A. Information Needed to Protect the Right of Access}

Once the government establishes the public's First Amendment right of access to docket sheets, it becomes important to examine the contours of that right. A docket sheet that lists the parties as "Sealed v. Sealed" and does not record any of the proceedings or filings in the case will frustrate any attempts to monitor or participate in judicial proceedings. On the other hand, by inspecting a docket sheet that lists the parties' names and records all of the significant actions in a case, the public can investigate the prevalence of certain types of cases, the nature of the parties to particular kinds of actions, and the types of materials that courts are likely to seal. ${ }^{213}$ This Comment argues that the First Amendment requires, at a minimum, that a publicly accessible docket list the names or pseudonyms of the parties (the case's caption), as well as any motions, hearings or orders regarding the sealing of documents or proceedings. In addition, the government must give members of the public access to this information in a timely manner so that they have the opportunity to attend proceedings and to oppose motions to seal. These minimal requirements will ensure that the public knows of the existence of an action and has an opportunity to voice objections before courts seal proceedings and filings.

\section{Case Captions}

The right of access to dockets must include the right to view the names of the parties to the action or their pseudonyms. ${ }^{214}$ Even when anonymous parties litigate a case, access to the case caption ensures that the public at least knows that parties are pursuing an action; thus, parties do not litigate in complete secrecy. Moreover, a rule requiring access to litigants' names, absent special circumstance justifying a pseudonym, prevents courts from operating dual-docketing systems, like the one exposed in Connecticut, in which the elite received an unjustifiable degree of privacy. At a bare minimum, "[the public] need[s] to have a public docket that reflects cases;" otherwise, "there's absolutely no safeguard against abuse."215

213. Hartford Courant Co. v. Pellegrino, 380 F.3d 83, 96 (2d Cir. 2004).

214. A discussion of the circumstances in which pseudonymous litigation might be beneficial is beyond the scope of this Comment. For arguments supporting claimant anonymity in civil cases, see Jayne S. Ressler, Privacy, Plaintiffs, and Pseudonyms: The Anonymous Doe Plaintiff in the Information Age, 53 Kan. L. Rev. 195 (2004).

215. Dan Christensen, Secrecy Appealed, Daily Bus. Rev., Sept. 26, 2003 at A1 (quoting an attorney's reaction to the Bellahouel case). 


\section{Docket Entries Regarding Motions and Orders to Seal}

The right of access to dockets must include the right to view docket entries regarding motions to seal, hearings on motions to seal, and sealing orders. The docketing of motions to close a proceeding or seal documents provides notice to the public that a motion has been made. ${ }^{216}$ Docketing such motions sufficiently in advance of the hearing on a motion affords the public and the press an opportunity to object. ${ }^{217} \mathrm{~A}$ court must also docket a closure or sealing order so the public can monitor the frequency of such orders and the type of cases that employ them.

This is not to say that the text of the motions in favor or opposition to sealing should be publicly accessible. To permit parties to explain to the court in detail why secrecy is necessary without jeopardizing their interests, it may be necessary in some instances to keep the text of the motion sealed. ${ }^{218}$ But the public must at least have notice that a sealing motion was filed and adjudicated, which a court can accomplish by docketing these procedures. Allowing secret filings of motions to seal "defeats the purpose of the system and undermines the credibility of the courts." ${ }^{219}$ A court renders government action immune from public scrutiny when a court's order to seal a case is itself secret. This is especially true in the rare instance in which a court finds it appropriate to seal a case completely, including its docket sheet. Before taking such a radical measure and hiding the very existence of a case from public view, courts must provide notice by docketing motions and hearings on the proposed closure.

\section{Timely Access to Docket Sheets}

Courts ought to provide members of the public access to docket sheets in a timely manner so that they may attend proceedings and oppose any motions to seal. The public cannot effectively monitor the judicial system if courts keep docket sheets sealed until years after an action has concluded. The right of access becomes so diluted as to be meaningless if the public does not have notice of proceedings until it is too late to observe.

\footnotetext{
216. In re Search Warrant, 855 F.2d 569, 575 (8th Cir. 1988)

217. Id.

218. See United States v. Haller, 837 F.2d 84, 87 (2d Cir. 1988); In re Washington Post Co., 807 F.2d 383, 391 (4th Cir. 1986); In re Knight Publishing Co., 743 F.2d 231, 235 n. 1 (4th Cir. 1984); In re lowa Freedom of Information Council, 724 F.2d 658, 662-63 (8th Cir. 1983); United States v. Criden, 675 F.2d 550, 559-60 (3d Cir. 1982).

219. Daily Business Review, South Florida Judges, Lawyers Question Judge Paul Huck's Actions in Bringing Secrecy to Extreme Level in Case Linked to Terrorism Probe, Mar. 19, 2004, http:/www.dailybusinessreview.com/AwardStories/WhyDidHeDolt.html (quoting an attorney's reaction to the sealing of dockets in the Bellahouel case).
} 
Timing is especially critical in regard to motions for sealing, where participation of the public and, especially, the press ${ }^{220}$ ensures that courts understand that the effects of sealing go beyond the parties to the action. ${ }^{221}$ Even in cases where both parties agree that the proceeding should be sealed, notice to the public is essential because the community's interests in the proceedings may differ from those of the parties. ${ }^{222}$ For example, in a product-liability lawsuit, the defendant corporation may move for sealing of proceedings and documents to protect its reputation. The plaintiff may agree to the sealing to increase her chances of a favorable settlement and to avoid appearing litigious. The public, however, may have an interest in maintaining the transparency of the proceedings and filings because they might relate to general health and safety. To ensure that the public's interests are adequately represented, the court must promptly enter in the public docket a party's motion to seal a proceeding. ${ }^{223}$ Without the public notice that docketing provides, no one other than court personnel and the parties to the action may ever be aware of the sealing motion or the underlying facts of the case should the motion be granted.

Although this Comment argues that dockets should be open in the vast majority of cases, it recognizes in the next Section that there are instances in which sealed dockets may be necessary to protect the privacy and safety of parties involved in specific types of proceedings.

220. This Comment takes no position on whether the press ought to be entitled to greater access to the courts (including their docket shects) than the public as a whole. Rather, the Comment uses the public's interest in access to docket sheets as its baseline. For an argument that the press should receive enhanced access to government-controlled information, see Timothy B. Dyk, Newsgathering, Press Access, and the First Amendment, 44 STAN. L. Rev. 927 (1992).

221. The Supreme Court has not clearly dictated the procedures that courts must follow in providing notice to the public of hearings to seal criminal proceedings. A footnote to the majority opinion in Globe Newspaper states that "representatives of the press and general public 'must be given an opportunity to be heard on the question of their exelusion."' 457 U.S. at 609 n.25 (citing Gannett Co. v. DePasquale, 443 U.S. 368,401 (Powell, J., concurring)). The necessary procedures for affording that opportunity remain uncertain. Justice Powell's concurring opinion in Gannett expressed the view that "this opportunity cxtends no farther than the persons actually present at the time the motion for closure is made." 443 U.S. at 401. Four Justices in Gannett (Blackmun, Brennan, White, and Marshall) stated that there must be an opportunity for protest by "any person removed from a court." Id. at 445 (Blackmun, J., concurring in part and dissenting in part). These Justices did not indicate whether that limited opportunity suffices in situations where no member of the public or press is present at the time a courtroom is closed.

222. See In re Herald Co., 734 F.2d 93, 102 (2d Cir. 1984) ("Since by its nature the right of public access is shared broadly by those not parties to the litigation, vindication of that right requires some meaningful opportunity for protest by persons other than the initial litigants, some or all of whom may prefer closure.").

223. See United States v. Haller, 837 F.2d 84, 87 (2d Cir. 1988) (adopting this procedure for motions to seal plea agreements). 


\section{B. Potential Cases Warranting Sealed Dockets}

The Supreme Court has held that closure of criminal proceedings can be ordered only if (1) closure is essential to preserve higher values than the public's right of access; (2) there is a substantial probability that, in the absence of closure, those values would be harmed; and (3) there are no reasonable alternatives to closure that would adequately protect those values. ${ }^{24}$ This Section applies these criteria to examine instances in which higher values outweigh the public's right of access to docket sheets. The Section begins with two relatively uncontroversial examples, adoption proceedings and juvenile prosecutions, and moves to an example that is more debatable, multi-defendant prosecutions.

\section{Adoption Proceedings}

By law or court rule, several states mandate that courts seal adoption dockets. ${ }^{25}$ The first prong of the Supreme Court's test for denying First Amendment access requires proof that closure is essential to preserve higher values than the public's right of access. Here, at least one of the higher values that society seeks to protect is the privacy of biological and adoptive parents. ${ }^{226}$ Although the public has an interest in monitoring whether adoption proceedings are conducted in a fair manner, several states have made a policy decision that the need to facilitate adoptions by protecting parents' privacy outweighs the public's monitoring interest. Parents may be more willing to participate in the system if they have assurances that their identities will remain confidential. ${ }^{227}$

The second prong of the Court's test requires a substantial probability that, in the absence of closure, the higher values at issue would be harmed. If adoption dockets were open to public inspection, their potential exposure would undermine parents' privacy. Members of the public would be able to determine the names of parents who have terminated their parental rights and parents who have chosen to adopt, thereby compromising the privacy of such parents.

The third prong of the Court's test requires that there be no reasonable alternatives to closure. Here, the only alternative that would protect parents' privacy would be to use a case number and pseudonyms when entering adoption cases on the public docket, and to remove all identifying information from adoption docket sheets. This procedure could be burdensome and confusing for courts that handle many adoptions. Thus, for some courts, sealing adoption dockets may be the only alternative.

224. Press-Enter. II, 478 U.S. 1, 13-14 (1986).

225. See supra note 44.

226. See Alma Soc. v. Mellon, 601 F.2d 1225, 1235-36 (2d Cir. 1979).

227. Id. 


\section{Juvenile Prosecutions}

Several states have enacted court rules and legislation requiring that courts seal juvenile justice dockets. ${ }^{228}$ In many instances, the sealing of juvenile docket sheets will meet the requirements of the Supreme Court's three-prong closure test. First, protecting young offenders' privacy by removing their names from public dockets often outweighs the public's interest in monitoring juvenile proceedings. Involvement in the juvenile justice system can stigmatize some offenders well into adulthood. ${ }^{229}$ For example, employers or landlords who examine criminal dockets may be unwilling to hire or provide housing for former juvenile offenders, even if the offense is several years old. ${ }^{230}$ Second, allowing public access to juvenile justice dockets has a substantial probability of undermining juveniles' privacy because members of the public will know the names of youths who have been subject to prosecution. As noted above, it is not unusual for employers or housing agencies to examine criminal dockets to determine whether a potential tenant or employee has a record. Third, much like the adoption context, the only alternative to sealing would be to use case numbers and pseudonyms when entering juvenile cases on the public docket and to redact identifying information from docket sheets. Given the sheer number of juvenile justice proceedings in many jurisdictions, this procedure may be unworkable for courts, and sealed dockets may be the only means of preserving juveniles' privacy.

There are instances, however, in which the public's interest in monitoring juvenile proceedings will outweigh juveniles' privacy interests, and sealing the dockets in such cases would thus fail the first prong of the Court's test. In high-profile violent crimes, for example, the public has a significant interest in examining whether the court conducted its proceedings in a fair manner and in discussing whether a proceeding's outcome was just. Jurisdictions can address these concerns by enacting laws or court rules ${ }^{231}$ specifying that juvenile dockets involving violent crimes shall be open to the public. Society may prefer such tailored rules to blanket laws that seal all juvenile dockets, because blanket laws might overly restrict access to juvenile proceedings of significant public interest.

\section{Multi-Defendant Prosecutions}

Access to docket sheets in multi-defendant prosecutions warrants careful examination because access raises several difficult problems. Case

228. See supra note 43.

229. See T. Markus Funk, A Mere Youthful Indiscretion? Reexamining The Policy Of Expunging Juvenile Delinquency Records, 29 U. Mich. J.L. REFORM 885, 888-89 (1996).

230. Id. at 888-89.

231. The use of court rules and legislation to vindicatc the First Amcndment right of access to dockets is addressed in detail in Part IV, infra. 
law and a recent study suggest that sevcral instances of docket sealing have involved multi-defendant prosecutions. ${ }^{232}$ Criminal cases in which courts have typically sealed dockets involve drug and murder conspiracy charges. ${ }^{233}$ Docketing such proceedings could alert co-conspirators that a criminal-defendant-turned-informant has agreed to aid the prosecution. ${ }^{234}$ This may not only impede law enforcement's continued use of the informant to gather information, but it may also put the informant's safety at risk. As a result, protecting the defendant's safety and an ongoing investigation may very well justify sealing the docket.

On the other hand, the Supreme Court has held that the public has a First Amendment right to attend criminal proceedings, and sealing dockets in cases involving multiple defendants would preclude the public from attending such proceedings. Further, a criminal defendant may need to inspect a codefendant's docket sheet so that he can determine whether his codefendant accepted a plea or whether the codefendant's case was resolved at trial. ${ }^{235}$ Such information may be essential im helping a criminal defendant to plan his pleading or trial strategy.

Despite the conflicting interests involved, in some instances the sealing of dockets in multi-defendant prosecutions likely will satisfy the Supreme Court's three-prong test for closing criminal proceedings. First, many courts are likely to find that a codefendant's safety and the government's interest in preserving a criminal investigation outweigh the public's interest in access to criminal proceedings. Second, there is a substantial probability that allowing public access to docket sheets in multi-defendant prosecutions could imperil a codefendant's safety by revealing whether the codefendant had recently appeared in court, accepted a plea, or was scheduled to appear at a future date. Third, using pseudonymous docketing as an alternative to entirely sealing the docket might not adequately protect the defendant's identity. In jurisdictions in which the media closely monitor criminal dockets, using a pseudonym might actually draw attention to a criminal case. ${ }^{236}$ Further, the defendant's co-conspirators might deduce that he is the pseudonymous defendant if their attorneys cannot locate his name on the public docket.

If a multi-defendant prosecution meets the three criteria above, this Comment recognizes that sealing the docket is permissible, but it argues

232. See United States v. Ochoa-Vasquez, 428 F.3d 1015, 1022-23 (11th Cir. 2005); Mitchell \& Burgess, supra note 2, at 4.

233. Mitchell \& Burgess, supra note 2, at 4.

234. Id. at 6 (noting that Washington, D.C., prosecutors noticed that criminals used public court records to spot cases in which nothing had happened since an arrest; the criminals concluded that defendants in such cases were cooperating and often retaliated by killing them).

235. Id.

236. See Roscoe Pound lnstitute, Open Courts with Sealed Files: Secrecy's Impact on AMERICAN JUSTICE 89 (2000) (noting that several state court judges reported that sealing records may itself invite scrutiny from the media). 
that courts should implement three procedures to protect the interests of the public and codefendants. First, both the prosecution and defense must agree to seal the docket. Requiring both parties to agree increases the likelihood that the reason cited for sealing (i.e., the defendant's safety) is a plausible one. Further, it reduces the risk that the government's motion to seal will thwart the defendant who wants public scrutiny of his case. Second, the court's order for sealing the docket must provide that sealing will terminate upon a particular date or condition. Although timeliness is an essential component of a meaningful right of access to dockets, delayed docketing of information may be justified to protect the safety of an informant-defendant. $^{237}$ Once authorities complete the criminal investigation and the informant's safety is no longer at risk, however, the justification for sealing the docket is extinguished, and the court should open the contents of the docket to the public. Third, courts must make transcripts of the proceedings available for public inspection after the docket has been unsealed. This ensures that the public can at least discuss and publish information regarding the criminal proceeding after the matter has concluded.

In sum, if a request to seal a docket meets the Supreme Court's threeprong test for closure, and if a court employs procedures that protect the public's right to have at least limited access to the case, sealing a docket in a multi-defendant case may constitute a necessary exception to the First Amendment right of access. ${ }^{238}$

\section{IV}

\section{Methods To ImPlement And Protect The Right Of Access To Dockets}

This Comment has argued that there is a First Amendment right of access to docket sheets that courts must recoguize and enforce. The current reality, however, is that the Supreme Court has not yet had an opportunity to recognize such a right, only two circuit courts have held that such a right exists, and few state courts have examined the matter. Further, as this Comment has discussed, case law and news reports indicate that both state and federal courts continue to seal dockets in a variety of matters. Finally, because docket sealing conceals the very existence of a case, members of the public may not be aware that the practice is taking place, making it difficult to hold judicial officials and attorneys accountable for the practice. All of this suggests that until courts widely recognize docket

237. United States v. Haller, 837 F.2d 84, 87 (2d Cir. 1988) (noting that docketing may be delayed in "extraordinary situations" when an individual might be at risk).

238. The analysis and procedures described above eould also be used to determine whether a doeket should be sealed in terrorism and similar cases implicating national security. 
sealing as an unconstitutional practice, advocates must take affirmative steps to vindicate the First Amendment right of access to docket sheets.

This Part examines three approaches that members of the public might take: (1) under a First Amendment theory, initiate litigation challenging either an individual instance of docket sealing or an entire system of secret docketing; (2) lobby legislators to adopt laws that limit the practice or that mandate the courts to develop guidelines regarding the practice; and (3) pressure courts to adopt rules restricting the practice. Each tactic has strengths and weaknesses, and the public might reach an ideal result by employing a combination of the three approaches.

\section{A. Litigation}

Litigation has been effective in unsealing closed dockets once the press and public have become aware that the practice was taking place. ${ }^{239}$ Challenges to sealed dockets typically have been brought under two First Amendment theories. ${ }^{240}$ First, parties have argued that access to docket sheets is a necessary prerequisite to exercising other rights guaranteed by the First Amendment, such as the right to attend criminal proceedings and to examine the transcripts of such proceedings. ${ }^{241}$ Second, parties have argued that access to docket sheets meets the two-prong experience-andlogic test, in that there is a long history of such access and the access enhances the fairness of the judicial system. ${ }^{242}$ Thus, in several cases litigation has vindicated the First Amendment right of access to docket sheets. ${ }^{243}$

Litigation has been brought to challenge both individual instances of docket sealing ${ }^{244}$ as well as entire systems of secret docketing. ${ }^{245}$ Challenges have been brought by codefendants in criminal prosecutions who need access to sealed case information to develop their defense strategies; ${ }^{246}$ parties to a case who want sealed case information to be open for public inspection; ${ }^{247}$ and journalists who have been unable to object to closed court proceedings or to report on such proceedings because sealed

239. See, e.g., Hartford Courant v. Pellegrino, 380 F.3d 83 (2d Cir. 2004); United States v. Valenti, 987 F.2d 708 (11th Cir. 1993); State ex rel. Cincinnati Post v. Court of Appeals, 604 N.E.2d 153 (Ohio 1992). But see M.K.B. v. Warden, 540 U.S. 1213 (2004) (denying petition for writ of certiorari in habeas corpus case in which district court and court of appeals had sealed docket entries).

240. These theories are discussed in detail in Part II.B, supra.

241. See, e.g., Valenti, $987 \mathrm{~F} .2 \mathrm{~d}$ at 715.

242. See, e.g., Pellegrino, 380 F.3d at 94.

243. See, e.g., id.; United States v. Ochoa-Vasquez, 428 F.3d 1015, 1029 (11th Cir. 2005); Valenti, 987 F.2d at 715.

244. See, e.g., Ochoa-Vasquez, $428 \mathrm{~F} .3 \mathrm{~d}$ at 1024.

245. See, e.g., Pellegrino, 380 F.3d at 86.

246. Ochoa-Vasquez, 428 F.3d at 1024-25.

247. See Petition for Writ of Certiorari, supra note 9, at 25-26. 
dockets have precluded access. ${ }^{248}$ In Ohio, for example, a reporter requested access to docket books containing entries for appeals filed by minors who had been denied court orders to obtain abortions without parental notification. ${ }^{249}$ The reporter was told that the court keeps these appeals in sealed docket books that were not open to the public. ${ }^{250}$ The newspaper then sought a writ of mandamus to gather information about appeals brought by minors under the state's judicial bypass statute. ${ }^{251}$ Recognizing that "open courts are required by the Constitution," the state supreme court held that for each judicial bypass case, the public was entitled to secure "(1) the docket number, (2) the name of the judge, and (3) the decision, including, if appropriate, a properly redacted opinion."252

A major shortcoming of a litigation-based strategy is that the public cannot initiate actions to unseal closed dockets if sealing has been so effective that no one, other than court personnel and parties to an action, knows that a case or even an entire system of secret docketing exists. The greater the secrecy surrounding the case, the less likely the public will be to detect the case's existence and bring suit. The court may conceal the very existence of a case by sealing the docket sheet, ${ }^{253}$ closing the proceedings, ${ }^{254}$ placing the parties under gag order, ${ }^{255}$ and barring court personnel from acknowledging that the case exists. ${ }^{256}$ When the court uses such tactics, the public may only be able to discover a case's existence if the court intentionally or accidentally reveals it, as occurred with the clerical error in M.K.B. v. Warden. ${ }^{257}$ Thus, advocates may be unable to uncover instances of secret docketing and subsequently challenge them under the First Amendment. As a result, prophylactic approaches, such as

248. Pellegrino, 380 F.3d at 86 ; Valenti, 987 F.2d at 715.

249. Cincinnati Post, 604 N.E.2d at 154. Ohio law permits minors to request judicial bypass of statutorily required parental notification before obtaining an abortion. OHIO REv. CoDE ANN. § 2151.85 (West 2005).

250. Id.

251. Id.

252. Id. at 156 .

253. See Hartford Courant v. Pellegrino, 380 F.3d 83, 87 (2d Cir. 2004) (describing dual docketing system in which court personnel were barred from releasing docket numbers and case captions to the public).

254. See De Vise, supra note 60 (reporting that press was barred from habeas corpus proceeding).

255. See Petition for Writ of Certiorari, supra note 9, at 23 (noting that parties and counsel in habeas corpus proceeding were under a court order prohibiting them from publicly revealing information about the proeeeding).

256. Pellegrino, 380 F.3d at 86 (deseribing dual docketing system in whieh court personnel were barred from acknowledging the existence of cases); Lynne Tuohy, No Docket, No Names; Cases Move in Secrecy, Hartford COURANT, Jan. 5, 2003, at Al (quoting executive director of external affairs for the Judicial Branch of Connecticut as stating that "Level 1 [sealing] means we can't even say the case exists").

257. See Petition for Writ of Certiorari, supra note 9, at 7 . 
the enactment of court rules and legislation, may be necessary to vindicate the First Amendment right of access to docket sheets.

\section{B. Legislation}

To vindicate the First Amendment right of access, advocates may lobby the legislature for laws that require courts to maintain open and complete docket sheets and that dctail the limited circumstances in which courts can seal dockets. ${ }^{258}$ In response to public outcry over the system of sealed docketing in the Connecticut courts, the State Senate introduced legislation to limit secrecy in the court system. The proposed bill required that "the names of the parties and the docket number in any civil or criminal matter in the Superior Court shall not bc kept confidential" in any future or pending cases. ${ }^{259}$ The Legislature did not enact the bill, mainly because the judiciary preempted the legislation by enacting its own rules to reduce secrecy. ${ }^{260}$ Even though the bill did not become law, this example illustrates that legislation may be an effective tooI in prompting the judiciary to take action and reform the system itself.

Although legislation restricting docket sealing may be preferable to court rules because it is less likely to be influenced by the will of the judiciary, efforts to enact legislation may encounter resistance from judicial personnel. In a recent report examining secrecy within the state courts, judges' opinions diverged considerably regarding whether legislation is needed to combat secrecy or whether courts should handle it themselves. ${ }^{261}$ Members of the judiciary "often bristle at attempts by the political branches to impose changes in [court] rules directly by legislation." 262 Further, because they are intimately acquainted with the workings of the courts, judges are perhaps in a better position than legislators to determine what procedures will best enhance openness in the courts.

To ease tension between the two branches, states might consider a hybrid approach in which the legislature directs the judiciary to adopt rules

258. Several states have long had laws requiring that courts open dockets to public inspection. See note 28 , supra. However, these laws alone may not provide sufficient guidance for courts, because they do not address the circumstances under which dockets can be sealed or the procedures that must be followed in ordering sealing.

259. Pellegrino, 380 F.3d 83, 87 (quoting S. 362, 2003 Gen. Assem., Jan. Sess. (Conn. 2003)).

260. See Lynne Tuohy, Judges Ban Secret Cases; Unanimous Vote Ends Practice of "SuperSealing" Civil Court Files, HarTford Courant, May 15, 2003, at Al (noting that judicial officials may have adopted rules regarding secrecy in order to stave off "legislative interference" in the court's rule-making function).

261. Roscoe Pound Institute, supra note 236, at 90.

262. Joseph F. Anderson, Jr., Hidden from the Public by Order of the Court: The Case Against Government-Enforced Secrecy, 55 S.C. L. Rev. 71 1, 746 (2004) ("Most judges are of the opinion that, left to our own devices, we are able to keep our house in order and make changes to our rules and procedures when circumstances warrant."). See also West, supra note 52, at A3 (describing the "power struggle" between the state legislature and the state supreme court over final rules on docket sealing). 
that limit docket sealing. Such an approach enables the legislature to make a policy decision regarding the type of cases in which privacy outweighs the public's interest in access. These could include adoption proceedings, juvenile prosecutions for nonviolent crimes, and multi-defendant prosecutions where an informant's safety would be jeopardized by public access. The legislature could also make policy decisions regarding the basic procedures that should be used in sealing dockets, such as requiring courts to notify the public that a motion has been filed seeking docket sealing or limiting the amount of time that a docket can remain sealed. Courts could then develop the detailed criteria and procedural rules necessary to carry out these policy decisions. In Texas, the legislature took this approach with respect to sealed records in civil cases, particularly sealed settlement agreements. ${ }^{263}$ The legislature directed the state supreme court to establish guidelines for state courts to use "in determining whether in the interest of justice the records in a civil case, including settlements, should be sealed." ${ }^{264}$ Thus, the legislature determined, as a policy matter, that it was necessary for the state to develop rules regarding the sealing of civil court records, such as settlement agreements, but responsibility for making these rules was left with the courts. Similarly, a legislature could direct its courts to establish guidelines that protect the public's right of access to docket sheets, but that also detail the criteria and procedures required to seal dockets in adoptions, juvenile prosecutions, and certain multi-defendant prosecutions. Examples of court rules that detail procedures required for docket sealing are discussed in the next Section.

\section{Court Rules}

Advocates and legislators may seek to vindicate the First Amendment right of access to docket sheets by urging courts to adopt rules requiring that docket sheets be open to public inspection, specifying the narrow circumstances under which dockets may be sealed and dictating the procedures that courts must follow when sealing occurs. Thus, court rules can serve a dual purpose of explicitly recoguizing a right of access to docket sheets and protecting this right by detailing the procedures that courts must follow before the right can be restricted. In the U.S. District Court for the Northern District of Oklahoma, for example, local rules provide that as a policy matter, sealed documents are disfavored. ${ }^{265}$ Titles of pleadings, including sealed pleadings, are docketed and open to the

263. See Tex. Gov't CoDE $\S 22.010$ (2005).

264. Id.

265. N.D. OKLA. LOCAL R. 79.1 (2005) 
public. ${ }^{266}$ Sealing may be approved by the court "only upon a showing that a legally protected interest of a party, nonparty or witness outweighs the compelling public interest in disclosure of records." ${ }^{267}$ After three months, documents may be automatically unsealed without notice to counsel. ${ }^{268}$

After newspaper reports revealed the existence of sealed dockets, judicial systems in Connecticut and New Hampshire adopted court rules in response to pressure from the public and legislators. ${ }^{269}$ Connecticut's provisions mandate that the judiciary notify the public of potential closure of the courtroom or sealing of materials, that judges articulate the overriding interest in closure or sealing and specify findings, and that the court narrowly tailor any closure or sealing order to protect the privacy interest at stake. ${ }^{270}$ New Hampshire's provisions focus on ensuring that the public is able to review a court's sealing order. Under the rule that the state supreme court adopted, "Every order of the supreme court that a case record or a portion of a case record is confidential shall be available for public inspection. Information which would compromise the court's determination of confidentiality, e.g., the name of a juvenile, shall be redacted."271

Some may question whether courts will follow their own rules restricting docket sealing. After all, what guarantee does the public have that a judiciary that only recently conducted proceedings in complete secrecy will suddenly abandon such practices to comply with a newly created rule? Simply having rules on the books that require public access to docket sheets and that permit sealing only under limited circumstances could mitigate such concerns. Aware of such rules, members of the public will be more likely to look for docket sealing and challenge the practice when they suspect it is taking place. Further, the presence of such rules may be a first step in changing a culture of secrecy within a court. Court rules explicitly communicate to judges and attorneys that there is a public right of access to docket sheets, and docket sealing thus should only be allowed if compelling circumstances warrant it. Additionally, the court

266. Id. Similarly, the U.S. District Court for the Eastern Distriet of North Carolina requires that when material is filed under seal, the docket must indicate the type of document filed under seal. See E.D.N.C. LOCAL R. 79.2 (2005).

267. N.D. OKLA. LOCAL R. 79.1 (2005)

268. Id.

269. See Hartford Courant Co. v. Pellegrino, 380 F.3d 83, 87 (2d Cir. 2004). After parties filed litigation to unseal dockets, the Connecticut judiciary enacted new rules that offered additional protections to the public's rights of access. See id. at 87 . The Connecticut Legislature considered but did not pass legislation this issue. Id. See also Nancy West, Court Adopts Temporary Rule on Confidentiality, N.H. Sunday News, July 8, 2001, at A3 (reporting that in response to public outcry over sealed dockets, state supreme court adopted temporary rule outlining procedures to seal records).

270. See ConN. Practice BoOK $\$ \S 11-20$ (c)-(e), 11-20A (2004) available at http://www.jud.ct.gov/Publications/PracticeBook/pb2005part1 .pdf.

271. Rule 12, Rules of the Supreme Court of the State of New Hampshire, available at http://www.courts.state.nh.us/rules/scr/scr-12.htm. 
must follow rules that dictate procedures for sealing the docket. Rules requiring public notification and mandating that parties articulate the overriding interest in sealing and judges make specific findings, reduce the ease with which secrecy can be obtained. This may discourage attorneys from seeking sealed dockets and judges from granting such requests.

\section{CONCLUSION}

Although docket sheets provide relatively minimal information, the indexing function this information serves makes access to docket sheets a necessary predicate to the exercise of the First Amendment rights of speech and press. Because access to docket sheets is an essential prerequisite to scrutinizing the courts, protection of this right of access inheres in the freedom of speech and press. Sealed dockets have precluded individuals from discussing and publishing information surrounding cases in which the public has a significant interest, such as the September 11 related habeas corpus proceedings in M.K.B. v. Warden. In the Connecticut judicial system, sealed dockets created an entire system of secret justice and potentially restricted discourse on matters involving the courts, such as actions brought against prison wardens and clergy members. Litigation, legislation, and court rules may be necessary to vindicate the First Amendment right of access to docket sheets and to prevent future restrictions on the public's ability to discuss the business of the courts. Certainly, parties will continue to take extensive steps to cloak litigation in secrecy, and a First Amendment right to inspect docket sheets thus cannot assure access in every case. However, it remains an essential component in eliminating secret court systems, such as those that once existed in Connecticut and New Hampshire. In the end, the most valuable feature of exercising a right of access to docket sheets may be its ability to act as a small yet influential step toward challenging systems of entrenched secrecy. 